
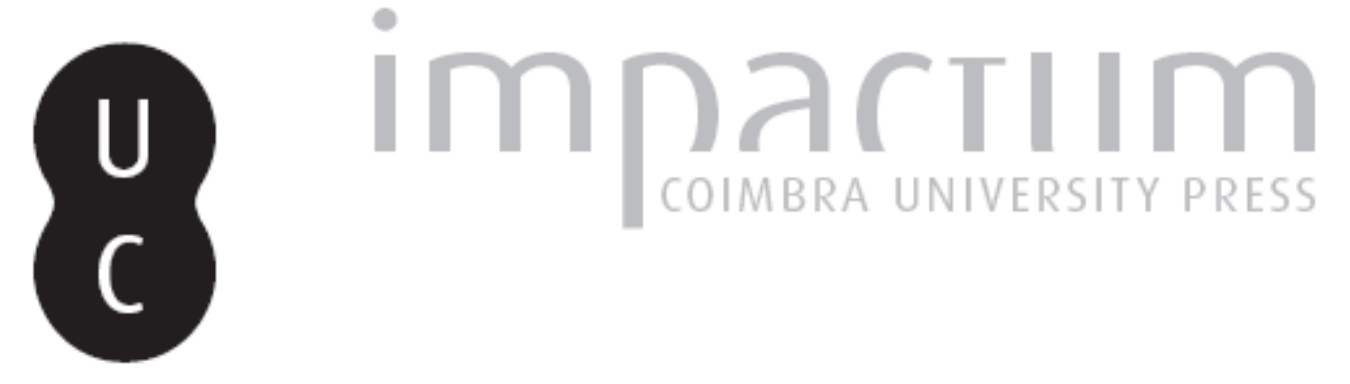

\title{
Política, história e revolução em Antero de Quental
}

\section{Autor(es): $\quad$ Catroga, Fernando}

Publicado por: Imprensa da Universidade de Coimbra

URL persistente:

URI:http://hdl.handle.net/10316.2/43738

DOI:

DOI:https://doi.org/10.14195/2183-8925_13_1

Accessed : $\quad$ 26-Apr-2023 11:18:23

A navegação consulta e descarregamento dos títulos inseridos nas Bibliotecas Digitais UC Digitalis, UC Pombalina e UC Impactum, pressupõem a aceitação plena e sem reservas dos Termos e Condições de Uso destas Bibliotecas Digitais, disponíveis em https://digitalis.uc.pt/pt-pt/termos.

Conforme exposto nos referidos Termos e Condições de Uso, o descarregamento de títulos de acesso restrito requer uma licença válida de autorização devendo o utilizador aceder ao(s) documento(s) a partir de um endereço de IP da instituição detentora da supramencionada licença.

Ao utilizador é apenas permitido o descarregamento para uso pessoal, pelo que o emprego do(s) título(s) descarregado(s) para outro fim, designadamente comercial, carece de autorização do respetivo autor ou editor da obra.

Na medida em que todas as obras da UC Digitalis se encontram protegidas pelo Código do Direito de Autor e Direitos Conexos e demais legislação aplicável, toda a cópia, parcial ou total, deste documento, nos casos em que é legalmente admitida, deverá conter ou fazer-se acompanhar por este aviso.

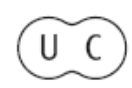


REVISTA DE HISTÓRIA DAS IDEIAS 13

\section{Antero de Quental}

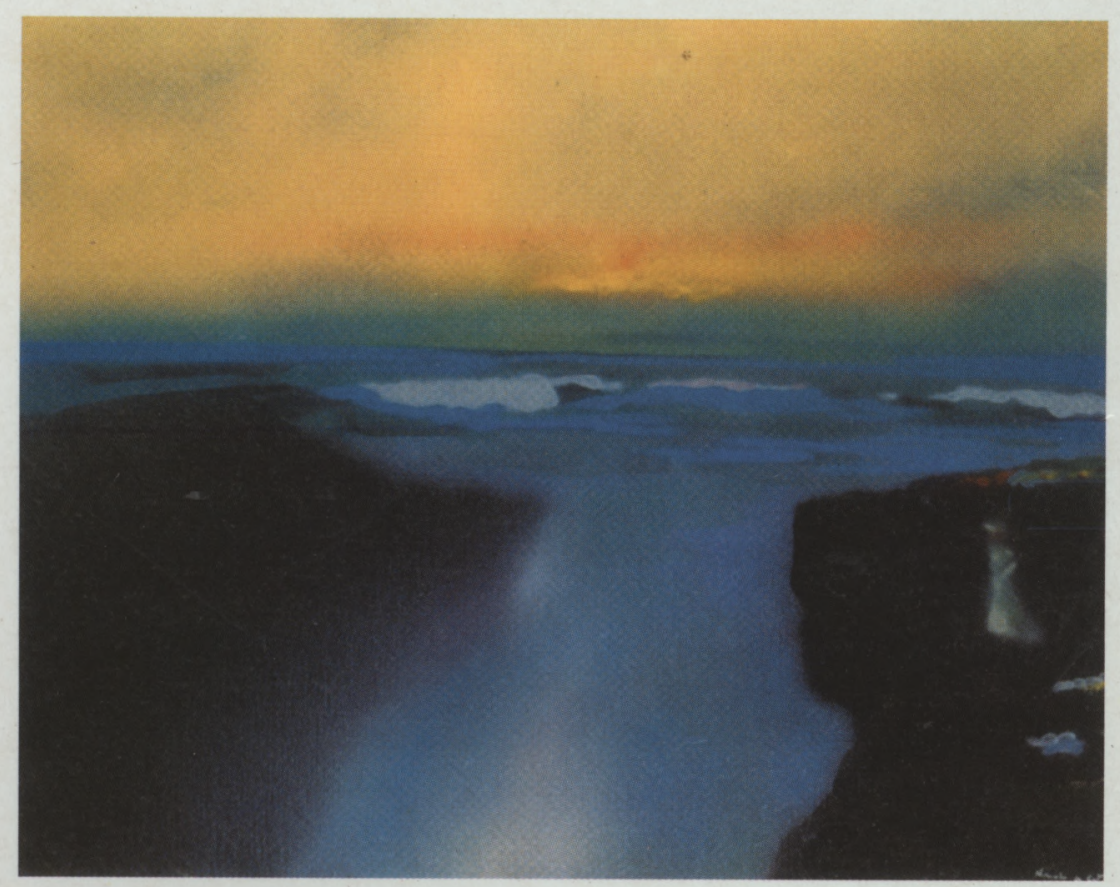

INSTITUTO DE HISTÓRIA E TEORIA DAS IDEIAS FACULDADE DE LETRAS

COIMBRA 1991 


\section{POLÍTICA, HISTÓRIA E REVOLUÇÃO EM ANTERO DE QUENTAL}

E para nós verdade inconcussa que a teoria e a prática políticas de Antero serão mal compreendidas se não forem interpretadas à luz da sua metafísica. É que, já em 1866, o filósofo-poeta pensava que a filosofia do futuro teria de resultar da sobredeterminação metafísica do positivismo $\left({ }^{1}\right)$, projecto que retomou nas décadas seguintes, conforme se pode ilustrar com o que sabemos acerca do plano do ensaio Programa dos Trabalhos para as Gerações Novas (1871-1875?) e do conteúdo dos seus escritos mais filosóficos dos finais dos anos 80 (Filosofia da Natureza dos Naturalistas e Tendências Gerais da Filosofia na segunda metade do século $X I X)$. Não admira que assim tenha sido, já que, se a sua geração foi a primeira que, na nossa cultura, tentou compreender 0 destino de Portugal dentro do horizonte diacrónico das filosofias da história inspiradas em Vico (Michelet), Hegel e Proudhon, foi também aquela que aderiu, algumas vezes um pouco dogmaticamente, à ideia de que tinha chegado a hora de tornar cientificamente transparentes as leis da história e de consumar a revolução, pelo que urgia "dar o íntimo pensamento da revolução em meia dúzia de ideias, claras, ligadas entre si e de que tudo naturalmente se deduzisse!" ( $\left.{ }^{2}\right)$. A lei dos três estados de Comte e a sua estática social, a dialéctica serial de Proudhon, o evolucionismo de Spencer, a etnologia, o darwinismo, foram algumas

\footnotetext{
* Faculdade de Letras da Universidade de Coimbra.

(') Antero de Quental, Prosas, vol. 2, Coimbra, 1926, p. 43.

(2) Idem, Cartas, vol. 1, Lisboa, 1990, p. 164.
} 
das propostas que, na diversidade dos seus argumentos teóricos e na diferença dos seus interesses, visavam transformar a política numa ciência social particular, ou, pelo menos, numa arte (entendida como aplicação das conclusões da sociologia).

Na conjuntura histórica em que se consolidou a formação intelectual de Antero, isto significava que a solução do problema social, e, portanto, a realização da ideia de revolução, não podia ser obra de voluntarismos subjectivistas - como acusou ter sido a insuficiência do utopismo da geração de 1848 -, mas teria de assentar numa base sólida e objectiva, que só a ciência poderia fornecer. Ora, se isto é verdade em relação a pensadores como Antero, Oliveira Martins, Teófilo Braga, Manuel Emídio Garcia e outros, importa porém lembrar que, no caso de Antero, a aceitação do valor (relativo e limitado) do conhecimento científico não dispensava a interrogação sobre os seus fundamentos e, consequentemente, sobre a realidade fenomenologica por eles referenciada $\left({ }^{3}\right)$. Isto equivale a dizer que, se a política tinha uma dimensão científica, esta só ganhava sentido, como teoria e como prática, a partir da sua justificação metafísica. E ́ a esta luz que se tem de compreender por que é que o socialismo anteriano é irredutível a um economicismo, ou a uma mera proposta de alteração de regime político, sendo simultaneamente tudo isso: "ciência e filosofia social: inclui pois, com a economia, direito, história e moral, mas tudo isto fundido e filosofado de uma maneira sui generis" $\left({ }^{4}\right)$.

\section{A POLÍTICA COMO CIÊNCIA ANTI-INDIVIDUALISTA}

Ao escrever no opúsculo $O$ Que é o Internacional (1871) que "a sociedade é um organismo, e os organismos transformam-se não se revolucionam" $\left({ }^{5}\right)$, Antero estava a explicitar o pressuposto ôntico da sua teoria da sociedade, concepção que pode ser sintetizada nos seguintes princípios, a saber: contra o contratualismo e contra o individualismo, definiu o homem como um ser naturalmente social e a

$\left({ }^{3}\right)$ Sobre as relações entre a metafísica e o conhecimento científico, veja-se Fernando Catroga, "A Metafísica Indutiva de Antero de Quental", Biblos, vol. LXI, 1985, pp. 472-507.

(4) A. Q., Cartas, vol. 1, p. 369.

(5) Idem, Prosas, vol. 2, p. 187. 
sociedade como "um organismo (...), um todo orgânico" $\left({ }^{6}\right)$. Porém, esta lição do historicismo romântico e de Herbert Spencer aparece corrigida pela influência de Proudhon, que lhe ensinou a ver a sociedade como uma realidade pluridimensional ( $)$. Daí que "na uniformidade, na homogeneidade de composição das sociedades democráticas" estivesse "o perigo todo" $\left({ }^{8}\right)$. E julgo que aqui radica tanto a sua aversão aos modelos centralistas e a sua apologia da descentralização e do federalismo, como as suas prevenções em relação ao sistema representativo centrado no indivíduo definido como autárcico átomo social. Em suma: a grande adversária da sociologia anteriana foi "a teoria do individualismo-naturalista-liberal" $\left({ }^{9}\right)$, o que significa que, na linha da sua leitura de Proudhon, perfilhou uma concepção monadológica da sociedade, cuja unidade, por isso mesmo, não podia ser "abstracta, exterior e material" $\left({ }^{10}\right)$, mas concreta, íntima e espontânea, porque, enquanto objectivação do Espírito, constituía uma "unidade orgânica desse ser vivo", e, portanto, uma "unidade na variedade", sendo esta especificidade, ao nível da realidade social, ditada pelas condicionantes históricas, mesológicas e étnicas. E tudo isto nos convida a fazer o paralelismo entre esta pluridimensionalidade social e a visão monadológica do cosmos $\left({ }^{11}\right)$, que a sua metafísica irá procurar fundamentar a partir do aprofundamento da influência de Leibniz $\left({ }^{12}\right)$. Por outras palavras: a grande tarefa política das novas gerações seria a de "criar a diversidade (garantia única da liberdade) na massa da nação" $\left({ }^{13}\right)$.

Simultaneamente, a articulação entre as séries ou as partes do real (dialéctica serial) não podia ser arbitrária. Antero, desde cedo, defendeu que a legitimação de qualquer ordem social tinha de radicar no "sentimento colectivo", e a transformação das sociedades só seria duradoura e radical se a reforma das instituições políticas fosse

( ${ }^{6}$ Idem, Cartas, vol. 2, Lisboa, 1989, p. 881 e Prosas, vol. 2, p. 209.

(7) Sobre toda esta questão, veja-se Fernando Catroga, "Filosofia e Sociologia. A ideia anteriana de socialismo", Vértice, vol. 42, n. ${ }^{\circ}$ 448, 1882, p. 296 ss.

(8) A. Q., Prosas, vol. 2, p. 63.

(') Idem, Cartas, vol. 1, p. 225.

$\left({ }^{10}\right)$ Idem, ibidem, vol. 2, p. 881.

('1) Já sugerimos esta homologia em Fernando Catroga, art. cit., p. 368.

$\left.{ }^{12}\right)$ Sobre a influência de Leibniz, veja-se Fernando Catroga, "A ideia de evolução em Antero de Quental", Biblos, vol. 56, 1980, pp. 358-88.

$\left({ }^{13}\right)$ A. Q., Prosas, vol. 2, p. 64. 
consequente às transformações económicas, devendo estas ser movidas, não pela exclusiva e omnipotente iniciativa do Estado, mas pela acção autónoma da sociedade civil $\left({ }^{14}\right)$. É que, para ele, a tarefa da revolução devia consistir na harmonização da política com a economia, sendoesta a substância da realidade social - nível em que se dava a exploração do trabalho (força colectiva) - e aquela, tão-somente, a expressão formal dessa substância $\left({ }^{15}\right)$. E se este posicionamento nos pode ajudar a compreender o sentido (relativo) do chamado anarquismo anteriano dosinícios dos anos 70, bem como o significado do seu "abstencionismo" político, é também a partir dele que temos de entender a compatibilidade que, na nossa opinião, existiu entre o seu republicanismo ideal e o seu permanente combate contra orepublicanismo rousseaunianoe jacobino historicamente continuado pela III República francesa e pelo nosso nascente Partido Republicano.

Com efeito, segundoo organicismo anteriano, as sociedades liberais, fossem monárquico-constitucionais ou republicanas, baseavam-se numa errada concepção "algébrica" e "abstrata" dos indivíduos, esquecendo-se que estes são seres concretos, que desempenham funções, estão inseridos num dado espaço, possuem uma dada herança histórica e pertencem a uma determinada raça. Assim, se se pretender anular a distância entre os indivíduos e o Estado (causada pela sociedade moderna nascida da revolução), a federação agrícola-industrial sociedade económica ideal propugnada por Antero - teria de ser enformada por uma reorganização política descentralista e por um sistema da representação alicerçado nos corpos sociais intermédios. Daí que ele tenha criticado o sufrágio universal e o parlamentarismo, aproximando-se, nesta matéria, de Proudhon e das teses que, inspiradas no socialismo catedrátrico, Oliveira Martins começou a defender desde os meados da década de $70\left({ }^{16}\right)$. E que esta sua opção se manteve nos anos seguintes, prova-o o teor da carta que, em 1888, endereçou a Jaime de Magalhães Lima, eonde voltou a defender algo de semelhante ao que já havia escrito na década de 70: "sendo a sociedade um

$\left({ }^{14}\right)$ Sobre a articulação das reformas políticas com as reformas económicas, leia-se Fernando Catroga, "O Problema Político em Antero de Quental. Um confronto com Oliveira Martins", Revista de História das Ideias, vol. 3, 1981, p. 347 ss.

(15) A. Q., Prosas, vol. 2, p. 51.

$\left({ }^{16}\right)$ Cf. Fernando Catroga, art. cit., p. 353 ss. 
organismo, a sua forma política deve ser orgânica, efectiva, e não abstrata, natural e não matemática" $\left({ }^{17}\right)$.

\section{FILOSOFIA DA HISTÓRIA}

Esta concepção acerca do homo sociologicus pretendia opor-se ao enaltecimento do homo economicus feito pelo liberalismo (Escola de Manchester) e às suas interpretações da realidade social baseadas no paradigma das ciências físico-matemáticas. É que, para Antero (como para Oliveira Martins), "la méthode des sciences sociales ne peut donc pas être abstraite: elle doit être, avant tout, historique" $\left({ }^{18}\right)$. Tal postura demarcava-se do que poderemos apelidar de interpretação individualista-iluminista da sociedade, com o claro propósito de mostrar que só na concretude orgânica a universalidade se realiza. E isto explica que ele, como bom romântico, tenha sido particularmente sensível ao debate sobre a definição do "espírito do povo" (Volksgeist), ou de alguns dos seus sinónimos ("génio da raça", "génio nacional"), e à discussão, então muito acesa, acerca das causas que determinam as suas especificidades. O que, no contexto polémico da época, nos envia directamente para o estudo das relações entre as sociedades e o meio, e, em particular, para a questão da influência da raça na história.

\section{Raça e História}

Antero é pela primeira vez explícito sobre esta questão na sua célebre crítica à obra de Teófilo Braga publicada, em 1871, sob o título Considerações sobre a Filosofia da História Literária Portuguesa. Em causa estava a tese teofiliana sobre a caracterização do "povo português" eda sua história, em que esta ficava reduzida a uma base dominantemente étnica, pois o seu dinamismo teria como motor principal a luta da raça moçárabe-genuinamente popular e verdadeiramente criadora-contra a aristocracia opressora de origem goda. Antero, em sintonia com as

(17) A. Q., Cartas, vol. 2, p. 881.

(18) Idem, Prosas, vol. 3, Coimbra, 1931, p. 3. 
críticas de Alexandre Herculano $\left({ }^{19}\right)$ e de Oliveira Martins $\left({ }^{20}\right)$, acusou de falaciosa a existência de tal raça, e criticou a fundamentação exclusivamente étnica da luta entre o povo e a aristocracia, porque, a seu ver, esta oposição constituía um "facto social e não etnológico, geral em toda a Europa" $\left({ }^{21}\right)$, e não exclusivamente português. Por isso, acusava Téffilo de ter-se limitado a aplicar à realidade portuguesa as ideias de Schlegel e da escola romântica alemã do começo do século XIX, que consideravam todas as obras civilizacionais "como a expressão genuína do génio da raça, subordinando a nacionalidade, em todas as suas manifestações, a um ponto de vista puramente etnológico" $\left.{ }^{(22}\right)$. Com isto, diremos nós, o intelectual republicano adaptava à realidade portuguesa a célebre "querela das duas raças", que há muito dividia a intelectualidade francesa, e que teve nos historiadores românticos (Thierry, Guizot e sobretudo Henri Martin) a sua melhor expressão, ao apresentarem a vocação democrática dos "galo-romanos" em oposição a aristocracia "franco-germânica", tendo os primeiros somenteemergido como vitoriosos a partir da Revolução Francesa $\left({ }^{23}\right)$.

Antero, aqui na linha do seu mestre Michelet, contestava a validade da aplicação exclusiva do argumento étnico aos povos europeus, pois estes seriam um produto de várias e complexas miscegenações. No entanto, não escamoteava por inteiro a importância do elemento rácico, já que, também para ele, "se o génio de cada raça fornece com efeito os elementos e como que a matéria prima das civilizações, a cultura e a tradição representam o trabalho de aperfeiçoamento doespírito humano, acumulado, que desenvolve aqueles elementos e, fazendo por assim dizer fermentar aquela matéria primitiva, lhes dá uma forma nova e superior" $\left({ }^{24}\right)$.

Recorde-se que esta polémica ocorreu numa conjuntura que era herdeira do grande debate - que a geração de Antero comparti-

\footnotetext{
$\left({ }^{19}\right)$ Alexandre Herculano, Cartas, t. II, Lisboa, s. d., pp. 33-35.

$\left({ }^{20}\right)$ J. P. Oliveira Martins, A Teoria do Mosarabismo de Teófilo Braga (Inédito), Coimbra, 1953.

(21) A. Q., Prosas, vol. 2, p. 221.

(22) Idem, ibidem, p. 215.

$\left({ }^{23}\right)$ Léon Poliakov, O Mito Ariano, S. Paulo, 1974, pp. 9-28.

(24) A. Q., Prosas, vol. 2, pp. 216-217. Os sublinhados são nossos.
} 
lhou $\left({ }^{25}\right)$ - sobre as origens da civilização europeia $\left({ }^{26}\right)$. E este tinha por base a crescente credibilidade das teses "indo-europeias" e "arianas", alicerçadas na extrapolação rácica de argumentos linguísticos decorrentes das interpretações de William Jones (1788)e seus seguidores sobre o sânscrito (reactualizadas por Grimm, Crutzer, Lassen, Max Müler, Renan, entre outros) e nas classificações propostas pela antropologia física e renovadas sob o efeito da "revolução darwiniana".

O "mito ariano" - não confundir com a sua versão pangermanista de origem multissecular e, de certo modo, já pressuposto na filosofia da história de Herder, recobriu-se com argumentos tirados das ciências e encontrou, a partir dos irmãos Schlegel e de Schopenhauer, um numeroso grupo de adeptos tanto na Alemanha como em outros países europeus (Victor Courtet, em França), e em relação aos quais a célebre obra de Gobineau Essai sur l'inégalité des races humaines (1853) é mais um ponto de chegada do que uma originalidade radical $\left({ }^{27}\right)$. Assim sendo, também não surpreende que o apelo ao "regresso às origens" típico do romantismo tenha sido compatível com o crescente peso das teorias étnicas na explicação da chamada "alma nacional", podendo-se dizer que as várias teses de raiz rácica só se diferenciavam entre si em função da invocação, ou não, de factores condicionantes (climatéricos, históricos, sociais, etc.) e a partir dos interesses políticos que as sobredeterminavam, diversificação esta que se traduziu nas divergências acerca das divisões internas da "raça ariana" e no peso crescente dos argumentos que visavam mostrar que o indianismo era sinónimo de germanismo.

Se tivermos presente o conjunto de obras que mais influenciaram os jovens intelectuais da geração de Antero, em muitas (Thierry, Guizot, Henri Martin, Renan, Taine-só para citarmos os franceses), a presença

${ }^{(25)}$ Com efeito, recordando as grandes polémicas que animavam as tertúlias académicas do tempode Antero, Eça escreveu: "Por todos os botequins de Coimbra não se celebrou mais senão essa rainha de força e graça, a Humanidade. Do meu poema não recordo nem o tema nem o título, e apenas que deveria abrir por uma tremenda inovação à Índia, aos Árias, à sua marcha sublime desde Gau até Spta-Sindhu!..." (Eça de Queirós, Obras. Notas Contemporâneas, 2." ed., Lisboa, s.d., p. 255).

$\left({ }^{26}\right)$ Léon Poliakov, ob. cit., p. 161 ss.

$\left({ }^{27}\right.$ Idem, ibidem, p. 197 ss.; Jean Boissel, Victor Courtet (1813-1867) premier théoricien de la hiérarchie des races. Contribution à l'Histoire de la Philosophie Politique du Romantisme, Paris, 1972, p. 10 ss. 
do argumento étnico é uma constante. E, no momento da polémica de Antero com Teofilo Braga, destacava-se o peso das ideias de Taine. $O$ que não admira, pois tratava-se de uma querela acerca da interpretação da história da literatura. Ora, dentro da sensibilidade romântica, ou pelo menos do romantismo social que influenciou Antero, a literatura (e, sobretudo, a poesia) não devia ser definida "como uma criação meramente individual, determinada apenas pelo sentimento pessoal, $o$ génio, as disposiçães do poeta"; ao invés, enquanto criação individual com raízes na colectividade, teria de ser compreendida como a consequência de "uma relação estreita entre a inspiração do indivíduo e o pensamento da época, a raça, o meio social, e o momento históri$c o$ " $\left.{ }^{28}\right)$, isto é, ser interpretada como a melhor "expressão do seu espírito nacional" ${ }^{29}$ ). Daí que se possa afirmar que, na arte, pelo menos nos seus melhores intérpretes, é o próprio "génio nacional" que se revela.

Nesta concepção, é patente a presença de Taine e da sua teoria acerca da conjugação do momento histórico, da raça e das instituições $\left({ }^{30}\right)$ na definição das especificidades das obras literárias e das literaturas nacionais. Um ano antes, Eça de Queirós, articulando-a com as teses de Proudhon, recorreu a ela na sua conferência do Casino, e agora Antero invocava-a para se contrapor às explicaçōes exclusivamente rácicas. É que, no fundo, as ideias de Taine limitavam-se a particularizar uma concepção acerca da condicionalidade histórica mais geral, em que o peso do contributo romântico, representado pela relevação das influências étnicas e histórico-institucionais na determinação das originalidades nacionais, aparece ligado, comoexemplarmente se pode encontrar em Michelet, com a valorização das condições climatéricas e geográficas na fixação do que, na época, também se chamava "o temperamento dos povos".

Em suma: para Antero, reduzir a compreensão do "génio nacional" ou da "alma nacional" a "um princípio único é querer de propósito acanhar a história" $\left({ }^{31}\right)$, porque essa tese é desapropriada quando aplicada "a uma nação sem base etnograficamente definida, como a

$\left({ }^{28}\right)$ A. Q., Prosas, vol. 2, p. 210 . Os sublinhados são nossos.

$\left({ }^{29}\right)$ Idem, ibidem, p. 224.

$\left({ }^{30}\right)$ H. Taine, Philosophie de l'Art, 7ème éd., Paris, 1895, p. 157 ss.

$\left.{ }^{31}\right)$ A. Q., Prosas, vol. 2, p. 217. 
portuguesa" ( ${ }^{32}$ ). É que a formação dos povos modernos não teve uma base fisiologica exclusiva, mas foi fruto de "elementos complexos, uns fatais outros livres, uns criados outros herdados, cuja síntese constitui a ideia da sua nacionalidade - raça, instituições, religião, tradição histórica, e vocação política e económica no meio dos outros povos" $\left({ }^{33}\right)$. Assim sendo, é a ideia nacional, na sua evolução histórica, que vai definindo, gradualmente, o chamado "temperamento da nação" ( $\left.{ }^{34}\right)$. No entanto, ao jovem Antero não repugnava aceitar o papel determinante da raça quando aplicado às chamadas "raças originárias", istoé, às raças que não eram o produto de complexas miscegenações, dado que, como se tratavam "de povos sem precedentes nem tradições de um mundo anterior, que começaram isolados o trabalho de civilização desde os seus inícios", as suas "criações representam apenas o fundo originário fornecido pelo carácter da raça, como foram os índios desde o Rig Veda até Kalidassa, os gregos até Alexandre, e os escandinavos até à conversão do cristianismo" $\left({ }^{35}\right)$, pelo que, só aí, a teoria etnológica é "rigorosamente verdadeira" $\left({ }^{36}\right)$.

Perante o exposto, pode concluir-se que, já nos inícios dos anos 70 , Antero estava atento ao debate acerca das relações entre a raça e a história. Todavia, os seus textos deste período não são ainda muito explícitos sobre o arianismo, embora já criticassem as versões pangermanistas que os intelectuais alemães, sobretudo após o desfecho da guerra franco-prussiana, tiravam das teses rácicas, cada vez mais caldeadas com argumentos inspirados no darwinismo social. De facto, em carta a Oliveira Martins datada de Agosto de 1874, denunciava a evolução naturalista das ideias de Strauss, presente em Der alte und der neue Glaube, por encontrar nelas o velho panteísmo mecanicista, "sombrio e fatal", agora articulado com "Hobbes e Darwin, a força, o 'struggle for life'", a fim de dar uma pretensa credibilidade científica à redução da história às "lutas das raças" e à

$\left.{ }^{(32}\right)$ Idem, ibidem, p. 218. Curiosamente, Antero recorria a esta concepção para corroborar a tese de Herculano e, em certa medida, a de Oliveira Martins, acerca dos factores que determinaram a emergência da nossa nacionalidade. É que, também para ele, a fundação da nação portuguesa foi uma "criação da política e não da natureza, das instituições, e não da raça" (Idem, ibidem).

${ }^{(33}$ Idem, ibidem, p. 224.

( ${ }^{34}$ ) Idem, ibidem.

${ }^{(35)}$ Idem, ibidem, p. 217.

$\left({ }^{36}\right)$ Idem, ibidem. 


\section{Antero de Quental}

colocação do Estado e da autoridade como "o seu deus social" $\left({ }^{37}\right)$. E a crescente popularidade destas ideias alem-Reno levava-o a ter receio das reivindicações pangermanistas e a prognosticar que "a Alemanha, se fizer alguma coisa boa (o que é problemático) será só para $\mathrm{si}^{\prime \prime}\left({ }^{38}\right)$.

Tais receios, porém, não contraditavam a grande admiração que o nosso poeta tinha pela cultura alemã, mas eram preventivos em relação aos perigos de imitação e de importação do modelo. Os temperamentos do povo português e do povo alemão eram diferentes, pelo que a análise do contributo civilizacional deste último devia ser feita "livremente, com o pleníssimo direito da crítica, e consultando sempre os seus íntimos instintos de latino, que eu sou e não me envergonho de ser" $\left.{ }^{(39}\right)$. E esta diferença entre germanos e latinos traduzia-se, afinal, numa diversa vocação histórica e, em última análise, numa diferente propensão para a transformação da sociedade. É que "há um génio latino, como há um génio germânico. A história o revela: e, quando a história fosse muda, a nossa consciência bradaria sempre, dando-lhe o seu nome. Revolução. É este o pensamento secular das raças latinas: a revolução moral, política e social (...) Os germanos, cuidando-se originais, fazem impérios: nós, latinos, desfaçamo-los. Reformam velhas religiões: prescindamos nós delas. Reconstituem com os milhões do espólio, uma nova aristocracia: dêmos nós aos povos a igualdade social" $\left({ }^{40}\right)$.

Perante a inexistência de qualquer referência ao fundo rácico comum a germanos e latinos, fica-se com a certeza de que, nesta época, Antero não invocava ainda o arianismo como a raiz em que germanos e latinos se integravam. O que não acontecerá a partir de 1875. Porém, antes de prosseguirmos, convém sintetizar a sua posição nesta matéria. É certo que não aceitava a exclusividade causal do argumento étnico na caracterização da índole do povo português (e dos povos europeus), conquanto a considerasse válida, como vimos, quando aplicada às chamadas "raças originárias". No entanto, já nos inícios dos anos 70, não deixava de definir, mesmo para os povos resultantes de misturas étnicas, a raça como a matéria prima sobre a qual a

\footnotetext{
$\left({ }^{37}\right)$ Idem, Cartas, vol. 1, p. 256.

$\left({ }^{38}\right)$ Idem, ibidem.

$\left({ }^{39}\right)$ Idem, Prosas, vol. 2, p. 239.

$\left({ }^{40}\right)$ Idem, ibidem, pp. 239-40.
} 
história e a acumulação das conquistas civilizacionais (a tradição) trabalhavam em ordem à obtenção do seu crescente aperfeiçoamento. Ora, com isto, o nosso pensador distanciava-se não só dos fundamentos exclusivamente biologistas apresentados por alguns adeptos da superioridade da chamada raça "indo-europeia" ou ariana (particularmente fortes na escola antropológica francesa - Broca, Victor Courtet, Quatrefages, Topinard), mas, como romântico, sugeria também que os factores étnicos, à boa maneira hegeliana, deviam ser determinados pelo devir do Espírito, o que exigia que a compreensão das relações entre a raça e a história não pudesse ficar confinada aos quadros do naturalismo e do mecanicismo, pois teria de ser interpretada, simultaneamente, do ponto de vista da ciência e do ponto de vista metafísico.

Com efeito, já nas Considerações sobre a Filosofia da História Literária Portuguesa, Antero invocava implicitamente o fundo hegeliano-proudhoniano do seu pensamento histórico (devir universal concretizado em termos de uma dialéctica serial) ao lembrar a Téfilo ser necessário compreender "que os momentos da história não são contraditórios entre si, mas representam vários termos duma série, por onde o espírito humano, ascendendo, se afirma, transformando em parte as condições do meio em que se move, e em parte subordinando-se a elas", e que, enquanto "este ponto de vista, ao mesmo tempo idealista e científico, se não estabeleceu - a história crítica, íntima, psicologica, era impossível, e impossível também a filosofia da história" $\left({ }^{41}\right)$. De facto, esta afirmação é coerente com a matriz idealista-materialista que os seus textos filosóficos posteriores procurarão fundamentar, e quer dizer que, se, na perspectiva da ciência, o "espírito nacional" resultava da síntese de um complexo de causas (em que a raça constituía a matéria prima), a sobredeterminação idealista obrigava a que se indagasse se aquelas não eram, afinal, efeitos reais e concretos de um princípio teleológico que as suscitava, na busca da consumação da universalidade do Espírito. É que, a não ser assim, a filosofia da história de Antero caía no mecanicismo fisicalista, que ele sempre rejeitou, já que, como bom hegeliano, desde cedo aderiu à ideia segundo a qual cabe à história (e à cultura), enquanto objectivação de um esforço

(41) Idem, ibidem, p. 209. 
de espiritualização do universo - que só o homem pode realizar -, vencer e superar os determinismos naturais. Logo, os que, como os materialistas mecanicistas e os darwinistas sociais, viam no devir humano "um simples prolongamento da natureza, só mais complexo, desconhec[iam] inteiramente o verdadeiro carácter da evolução" $\left({ }^{42}\right)$.

Queremos com isto dizer que as suas posições, no que concerne à explicação da motricidade histórica è̀ relevação (relativa ou absoluta) do argumento étnico, só ganham o seu verdadeiro significado se forem entendidas à luz dos seus fundamentos metafísicos, tese que se torna meridianamente clara a partir de 1875 , quando começou a ser mais explícita a ligação entre a sua filosofia da história e a missão que destinava à raça ariana, atribuindo a esta uma vocação metafísica decisiva - a de realizar plenamente o sentido do devir histórico. Com isto, Antero não estava a ser original, antes dava continuidade ao eurocentrismo étnico já teorizado por Herder nos finais do séc. XVIII, e traduzia, em termos genéricos, a capacidade que Hegel atribuía a um ramo específico da raça ariana (o povo germânico) - a sua maior propensão espiritualista e metafísica. Esta vocação contrastava com o génio dos povos latinos (nascido da mistura do sangue romano com o sangue germânico), que se manifestava numa cisão impeditiva de, como no germânico, o espírito se intuir como uma totalidade em que é objecto de si mesmo $\left({ }^{43}\right)$.

Os juízos de valor de Antero sobre a filosofia e a cultura alemães permitem-nos concluir que também não lhe repugnava a aceitação da maior tendência metafísica deste ramo da raça ariana. Todavia, não temos dúvidas de que recusava as teses dos que, actualizando a lição de Fichte, defendiam que só os povos alemães seriam genuinamente herdeiros dos indo-europeus, pois acabava por seguir a linha dos pensadores que, desde Herder e Jacob Grimm, integravam os vários povos da Europa, incluindo os de origem celta e os iberos, na grande família ariana. De facto, só assim se explica que ele qualifique a raça ariana como a "nossa raça" $\left({ }^{44}\right)$, grande família dentro da qual se integrava, com as suas particularidades, a população portuguesa e peninsular.

Não deve surpreender que a questão do arianismo - ainda que sem

\footnotetext{
$\left({ }^{42}\right)$ Idem, ibidem, vol. 3, p. 129.

$\left({ }^{43}\right)$ Cf. Léon Poliakov, ob. cit., p. 226.

$\left({ }^{44}\right)$ A. Q., Cartas, vol. 2, p. 882.
} 
as componentes anti-semitas a que habitualmente vinha ligada - tenha emergido no ideário anteriano. Como já se assinalou atrás, a busca das "origens" e a aceitação da superioridade da raça indo-europeia ou ariana passou a constituir um dos mitos dominantes em boa parte da "inteligência" europeia oitocentista da década de 60. E, em Portugal, o factor étnico, ainda que com ênfases diferentes, também começou a estar indissoluvelmente ligado à fundamentação da nossa especificidade no devir histórico e, particularmente, à justificação do papel de Portugal no contexto da chamada história universal (Antero, Teófilo Braga, Oliveira Martins, Alberto Sampaio, entre outros).

Para o que aqui nos interessa, é particularmente significativo o pensamento de Oliveira Martins sobre esta materia $\left({ }^{45}\right)$. Na verdade, recorrendo ao evolucionismo lamarckiano e darwinista $\left({ }^{46}\right)$, e ao organicismo sociológico então em voga, Martins procurou estruturar uma filosofia da história alicerçada numa cosmogonia e numa antropologia bem precisas, que postulavam a existência de uma "alma universal", que se manifestava como força vital em variadas formas de objectivação, cabendo à humanidade o estatuto de instância em que esse dinamismo psíquico inconsciente se realiza como razão. Por isso, cada esfera do universo constituía a tradução particular dessa energia universal, expressão que, no homem, podia concretizar-se como progresso. Porém, esta possibilidade estava dependente do modo como as sociedades, enquanto organismos, se comportavam, e variava em função da história concreta dos povos, do meio em que se inseriam e da constitucionalidade da raça a que pertenciam.

Neste contexto, a história era vista como a dinâmica imprimida por cada grupo nas guerras, conquistas einvasões, fruto da lei de propagação e da apropriação. E, no referente às relações das sociedades com o respectivo meio, Oliveira Martins, tal como Herder, concluía que, conquanto as condições de existência exerçam influência no desenvolvimento físico e moral das sociedades, o homem não era um

${ }^{(45}$ ) Sobre esta questão do pensamento martiniano, veja-se Jorge Seabra, Oliveira Martins. Raça e Filosofia da História, Coimbra, 1992 (exemplar mimeografado); Pedro Calafate, "História e Filosofia da História em Oliveira Martins", Prelo, n..$^{7}$, Abril-Junho, 1985, pp. 45-57.

$\left({ }^{46}\right)$ Oliveira Martins, Elementos de Antropologia. (História Natural do Homem), Lisboa, 1954, p. 66 ss. 
produto mecânico das suas condições mesológicas, pois, como escreveu no seu livro Raças Humanas, povos houve que em regiões favoráveis não se desenvolveram, verificação que lhe permitia afirmar que, tal como Herder já havia sublinhado, acima de todos os elementos para a diferenciação étnica deve colocar-se a capacidade ingénita da raça $\left({ }^{47}\right)$.

A raça é, deste modo, o principal veículo de objectivação da história. E, evocando as teses eurocêntricas e arianas $\left({ }^{48}\right)$, que, tendo a sua primeira grande matriz em Herder, foram desenvolvidas pelo romantismo da primeira metade do século XIX, Oliveira Martins defendia que, "no concurso das raças (...), o domínio coube à dos indo-europeus que adiante de todos chegaram a conquistar os elementos de uma acção que reage sobre todos os outros povos, para os avassalar, ou para os exterminar" $\left({ }^{49}\right)$. Assim, se o género humano teve uma origem comum (monogenia haeckeliana), o seu crescente processo de diferenciação e de individualização tornou os seus vários ramos irredutíveis e sujeitos a um desenvolvimento desigual, cabendo à raça ariana uma superioridade ingénita que, por isso mesmo, a instituiu como norma de historicidade dos outros povos, pelo que a história só atinge uma dimensão universal e progressiva na medida em que é, em última análise, "a história do progresso de um povo, no desenvolvimento homogéneo da sua cultura, na expansão crescente do seu número e da área submetida ao seu domínio. Que importam, neste sentido, as histórias particulares dos americanos, dos malaios, dos africanos, pois se sabe ou se confia em que o destino final do mundo é cair sob o império ariano? Por isso as histórias dos povos não arianos só nos interessam e só são dignas da nossa atenção, quando a sorte põe qualquer deles em contacto com essa civilização soberana que os há-de submeter ou exterminar" $\left({ }^{50}\right)$.

Qual o lugar de Portugal dentro desta vanguarda? Oliveira Martins integrava o povo português (resultado da miscegenação dos celtas com povos indígenas) nos povos peninsulares, e todos num dos

\footnotetext{
$\left({ }^{47}\right)$ Idem, Raças Humanas e a Civilisação Primitiva, 4." ed., Lisboa, 1921, p. 12.

$\left({ }^{48}\right)$ Idem, ibidem, vol. 2, pp. 245-246.

$\left({ }^{49}\right)$ Idem, ibidem, vol. 1 , p. 39.

$\left.{ }^{\left({ }^{0}\right.}\right)$ Idem, "Teoria da História Universal", Política e História, vol. 2, Lisboa, 1957,
} p. 12. 


\section{Política, História e Revolução}

ramos arianos, tendo-lhes cabido a missão concreta de, através dos descobrimentos e da colonização, criarem os meios necessários a mundialização ariana. Mas, se esse período foi o momento de apogeu da Península, foi, igualmente, o início da sua decadência, ilação que fundamentava a visãotrágica que ele tinha da história ibérica. Cumprida a sua missão universal nos alvores da modernidade, os povos ibéricos entraram num processo de esgotamento e de queda, pois o facho da vanguarda passou para os povos arianos do norte, cuja mentalidade, mais pragmática, menos heróica e menos susceptível de entusiasmo religioso do que a dos peninsulares $\left({ }^{51}\right)$, se adequava melhor às necessidades sociais e mercantis nascidas dos próprios descobrimentos $\left({ }^{52}\right)$, enquanto na Península, ao invés, medraram os valores que conduziram à crise: - o individualismo, o jesuítismo e o mero espírito de conquista $\left({ }^{53}\right)$.

Não erraremos muito se sustentarmos que estas ideias seduziram Antero, tanto mais que elas vinham ao encontro de uma das preocupações essenciais do seu ideário: diagnosticar as razões da decadência e da crise não só dos povos peninsulares, mas também da própria civilização ocidental. No fundo, elas compaginavam-se com a sua sensibilidade romântica, pois a concretude da história corrigia o universalismo iluminista, e os seus ritmos particulares apareciam integrados numa visão global, cujo sentido se enraízava no telos último da evolução do próprio cosmos. Oteleologismo da metafísica anteriana a issoobrigava, atribuindo à raça superior uma função reveladora e práxica, mediação que torna lícito que se pergunte se a vocação histórica daquela era uma consequência natural da sua idiossincracia, ou se, ao contrário, representava a manifestação fenomenológica de um finalismo de ordem metafísica.

Tudo isto visa sublinhar que, quanto a nós, existem evidentes afinidades objectivas entre o modo como Antero articulou as relações entre a filosofia e a missão histórica da raça ariana com a grande matriz das filosofias da história românticas de pendor étnico: a filosofia de

(') Idem, Historia da Civilisação Iberica, 7." ed., Lisboa, 1923, pp. 297-322.

${ }^{52}$ Cf. Idem, ibidem, p. 299 ss; sobre esta questão, veja-se Augusto Santos Silva, "Morte, Mediação, História em Oliveira Martins", Revista de História Económica e Social, n. ${ }^{\circ} 14,1984$, pp. 1-40.

(53) Oliveira Martins, Historia da Civilisação Iberica, p. 333 ss. 
Herder. Com efeito, nas suas Ideen zur Philosophie der Geschichte der Menschheit (1784-1791) - que, sintomaticamente, Edgar Quinet (um dos mestres da geração de 70) traduziu para francês -, o filosofo alemão inscreveu a sua visão da história da humanidade numa concepção teleologica da natureza que a filosofia da natureza do romantismo, particularmente com Schelling, desenvolveu: o universo é definido como um organismo destinado a desenvolver dentro de si organismos superiores, numa série ascendente em que a Terra ocupa uma posição singular entre os planetas por propiciar o meio mais adequado ao desenvolvimento da vida. Eénalógica desta hierarquia qualitativamente ascendente que a vida racional emerge como a realização posterior da vida vegetal, enquanto a vida humana concretiza a vida racional. Por conseguinte, é na esfera superior que verdadeiramente os graus antecedentes se realizam, pois cada estádio anterior mais não é do que um momento e uma fase preparatória para o advento do seguinte. $\mathrm{E}$, nesta escala qualitativamente evolutiva, somente se exceptua ohomem, porque, ao ocupar o cume da pirâmide, ele é um fim em si mesmo e o definitivo elo de ligação entre a realidade natural e a crescente espiritualização do mundo, que lhe cabe ir realizando na Terra.

Ora, se, por tudo isto, Herder parece ser um bom representante do humanitarismoiluminista de Setecentos, ocerto é que nele encontramos a primeira teoria conducente à fragmentação da espécie, que a sensibilidade romântica virá posteriormente a desenvolver. Como ente natural, a humanidade aparece dividida em várias raças, possuindo cada uma delas características físicas e mentais próprias decorrentes da influência do meio. Todavia, cada raça, uma vez constituída, define-se pelo seu tipo específico e permanente, determinado não só pela acção das influências externas, mas também pelas suas características inatas. Daí que a função particular de cada uma delas se manifeste no seu esforço para realizar oideal próprio inscrito, como matriz, na sua índole (síntese do inato e do adquirido).

E é neste horizonte que se tem de compreender o eurocentrismo de Herder. No seio desta humanidade fragmentada, destacava a raça cujo tipo superior exigiu uma concretização dinâmica e histórica, pois, em vez de permanecer estática, como outras raças, teve necessariamente de se desenvolver no tempo, porque é da sua índole aspirar a formas superiores de vida e de agir para as alcançar. E o centro desta vida histórica foi e é a Europa, em consequência das características da raça 
que a habita, e devido às particularidades favoráveis da sua geografia e do seu clima. Daí o evidente contraste entre o modo histórico como os povos europeus assumiram o seu destino e o imobilismo dos habitantes de África e dos povos indígenas da América.

Estas ideias, mediatizadas por novos argumentos tirados da linguística, da antropologia física e da etnologia em prol da demonstração da superioridade da raça indo-europeia ou ariana, tiveram a sua plena sistematização no decurso do século XIX. O que não admira, já que Herder, ao fragmentar a humanidade e ao articular os caracteres inatos da raça com as influências do meio, dava bons instrumentos à fundamentação romântica das origens e das especificidades nacionais (e nacionalistas). Mas, no seu pensamento, encontramos ainda uma contradição que o romantismo, apesar do seu explícito apelo ao peso da tradição e da história, não conseguiu resolver. De facto, como bem assinalou Collingwood, os caracteres psicológicos de cada raça eram tidos por ínsitos e uniformes, de modo que, em vez da concepção iluminista de uma natureza humana únicae de essência imutável, defendia-se agora a existência de várias raças irredutíveis entre si. E se o reconhecimento da acção do meio parece sugerir que cada uma delas era um produto da sua história, o certo é que a postulação da idiossincrasia típica de cada raça constituía, ao contrário, o pressuposto fundante da maior ou menor dimensão histórica de cada uma $\left({ }^{54}\right)$. Esta contradição prolongar-se-á no pensamento histórico romântico, visão em que o "espírito do povo" funciona como uma espécie de Sujeito omnipresente, que a história concreta se limita a explicitar, e, entre nós, é particularmente detectável em Oliveira Martins e, como veremos, na maneira como Antero concebeu as relações entre a missão da raça ariana e a história.

É certo que este não seguiu Herder no que concerne à negação da historicidade de outros povos não europeus. No entanto, em carta de 5 de Maio de 1888, Antero era explícito ao reivindicar, como característica essencial da raça ariana - diferentemente do que aconteceu com a China depois de Confúncio e dos povos maometanos depois do predomínio dos turcos -, a existência de uma constante mobilidade. E tal "tendência para o movimento e para mudança" seria "tanto maior quanto mais rico e forte for o génio da raça" e "quanto mais alto ele

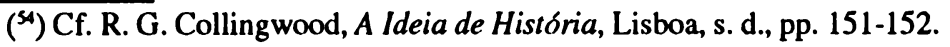


pairar com o seu pensamento sobre a realidade" $\left({ }^{55}\right)$. Esta tese ganha todo o seu significado se a inserirmos em algo que a filosofia da história de Herder já prenunciava, mas a que o historicismo hegeliano conferiu uma mediação mais inequívoca, a saber: cada raça tenderia a realizar o tipo de ideal próprio da sua idiossincrasia, e, uma vez aquele esgotado, o seu destino só podia ser a estagnação ou a morte. Dito por palavras de Antero: "as raças, que param, são as que chegaram até onde podiam chegar: as que se movem, movem-se porque ainda lá não chegaram, porque o seu ideal vai muito além da realidade social que construíram e não podem parar enquanto não tiverem realizado essa equação do seu ideal com as suas instituições, ainda correndo o risco de se agitarem indefinidamente, se, com efeito, esse ideal for irrealizável" $\left({ }^{56}\right)$.

Assim se vê que, no dinamismo histórico, algumas raças, porque mais insatisfeitas e inquietas, eram mais históricas do que outras. No entanto, qual era o critério que legitimava esta diferenciação? Não erraremos muito se sustentarmos que ele radicava na propensão para a idealidade de cada raça, ou melhor, na sua vocação metafísica, tendência que a impelia a ultrapassar, ou não, a realidade e a realizar, ou não, o que ainda não existia. Mas, tal como em Herder e em muitos futuros apologistas da superioridade ariana, também em Antero (e em Oliveira Martins) "o ideal, que estimula as sociedades ao movimento, édefinido e limitado pelas faculdades de cada raça, que são constantes e fixas" $\left.{ }^{57}\right)$. Deste modo, pode perguntar-se se, afinal, mais do que um produto da história, o "génio da raça", por muito que incorporasse, como naturais, as capacidades historicamente adquiridas, não constituía o resultado de uma matriz essencial e, portanto, ahistórica e natural.

Pelo que ficou exposto, não deve surpreender que Antero tenha defendido que a historicidade fosse um atributo natural da raça ariana, (exemplarmente expressa no idealismo objectivo alemão), pois, a seu ver, "a mobilidade das sociedades arianas é um facto constante, nunca desmentido e pode dizer-se que de ordem natural" $\left.{ }^{58}\right)$. É que, enquanto raça metafísica por excelência, a sua história, autêntica odisseia de 3000 anos, revelava que ela tinha o condão de "idealizar e transportar
$\left({ }^{55}\right)$ A. Q., Cartas, vol. 2, p. 878.
${ }^{56}$ Idem, ibidem. Os sublinhados são nossos.
$\left({ }^{57}\right)$ Idem, ibidem. Os sublinhados são nossos.
( ${ }^{58}$ Idem, ibidem. 
para um mundo superior todas as realidades em que toca", tendo por sua principal característica o já milenar esforço para hegemonizar uma visão do mundo que, como meta, propunha à humanidade a sua definitiva libertação do determinismo natural. Assim, enquanto as mundividências criadas pelas "raças sensualistas", ou melhor, pelas "raças inferiores", se saldavam num panteísmo espontâneo e bestial, subordinador da vida moral à imaginação e à tirania das sensações, o melhor da cultura produzida pelas raças arianas ensinava a ver o mundo de dentro para fora, porque, desde os alvores da filosofia grega, particularmente com Sócrates, e até ao idealismo contemporâneo, reivindicava a autonomia da consciência e a prioridade da actividade espiritual sobre o determinismo decorrente das concepções naturalistas, fossem estas derivadas do naturalismo espontâneo dos povos primitivos, ou fossem as teorizadas pelo materialismo mecanicista dos finais do século XIX. Daí que o domínio da mundividência suscitada pelo impacto das ciências da natureza na civilização ocidental, sem a necessária mediação espiritual, lhe aparecesse como uma espécie de reprodução intelectualizada de atitudes mais próprias de raças cujas culturas não conseguiam libertar o homem da sua subjugação à natureza.

Integrando esta posição eurocentrista e ariana no teleologismo da visão anteriana da história, isto significa que somente a cultura europeia poderia realizar conscientemente o sentido último do devir universal, dado que as aspirações para onde apontavam as ideias que a si mesma se propunha como ideal a atingir coincidiam com os interesses de toda a humanidade, "que a nossa raça", escreveu Anteroem 1888, "representa eminentemente" $\left({ }^{59}\right)$. Por conseguinte, impõe-se perguntar se o que é apresentado, em termos de explicação científica, como a consequência de uma predisposição natural, não constituía uma manifestação real, isto é, fisica e fenomenológica, de um postulado metafísico. $\mathrm{Na}$ verdade, se, para Antero, a história é, como veremos, o palco de objectivação do Espírito Universal, as raças, incluindo a raça ariana a raça "mais bem dotada" $\left(^{60}\right)$-, são, tal como os indivíduos, as classes sociais e afinal os povos, meros momentos da espiral das espirais que o grande todo evoluente vai desenhando, cabendo à raça ariana, devido

\footnotetext{
${ }^{59}$ Idem, ibidem, p. 882.

$\left({ }^{60}\right)$ Idem, ibidem, vol. 1, p. 311.
} 
à sua vocação filosófica, a função suprema de elevar a humanidade a consciência de si, enquanto nas demais esta assunção se dá de um modo inferior, istoé, de uma maneira limitada e inconsciente $\left({ }^{61}\right)$. A ser assim, também as raças estavam sujeitas à mediação dialéctica, mais não sendo, portanto, que instrumentos do Espírito. E é ainda à luz deste desafio - que, bem vistas as coisas, continha a possibilidade de a história (e a cultura) vencer o determinismo natural - que se jogava o possível desfecho da crise contemporânea. E esta era identificada por Antero como a crise da própria civilização ariana, estado em que se integrava, comouma das suas expressões específicas e mais dramáticas a decadência do povo português e dos povos peninsulares.

\section{Revolução e Crise}

O diagnóstico decadentista exigia como terapêutica o regresso à melhor tradição espiritualista da civilização ariana, pois só se re-espiritualizando a Europa poderia vencer os malefícios éticos e sociais provocados pelo prolongamento do fascínio acrítico pelas explicações científicas e técnicas, que tinham no positivismo e no monismo naturalista os seus fundamentos filosóficos, e no individualismo utilitarista a sua expressão política e económica por excelência. Ora, esta reconversão, "muito mais do que uma reforma política", exigia "uma reforma moral" $\left({ }^{62}\right)$, isto é, teria de eleger a realidade (e as conclusões das ciências) como "matéria prima" da reflexão filosofica. Porém, esta teria de elevar-se ao nível das intuições metafísicas em ordem a encontrar, no íntimo da consciência, o radical fundamento das coisas. $O$ que passava pela necessária reactualização da tradição espiritualista do pensamento indo-europeu. É que só a raça capaz de encarnar o destino da humanidade como um percurso ascendente poderia compreender que a verdade do Ser só asceticamente se revela.

Na verdade, a reivindicação da superioridade do espírito sobre a realidade remontava, segundo Antero, aos alvores da cultura ariana e teve as suas melhores traduções filosóficas no pensamento socrático e nos seus continuadores, num processo de continuidade do qual a

\footnotetext{
$\left({ }^{61}\right)$ Idem, ibidem, vol. 2, p. 879 .

(62) Idem, ibidem, p. 882.
} 
própria revolução cristã fazia parte, porque, no Cristianismo, "fossem quais fossem as suas origens", o que triunfou definitivamente, sobretudo com S. Paulo - "o verdadeiro fundador do Cristianismo" $\left({ }^{63}\right)$-, foi "o génio idealista-espiritualista ariano", o que sobressaiu foram "as liberdades mais íntimas e profundas da alma humana, não a sua escravização" ( $\left.{ }^{64}\right)$. Com esta tese, Antero estava de acordo com outros contemporâneos, nomeadamente com Burnouf, para quem "o Cristianismo é, em seu conjunto, uma doutrina ariana" $\left({ }^{65}\right)$, e era coerente com o papel que lhe atribuía na evolução psicológica e histórica da humanidade: sem o monoteísmo cristão não teriam sido reunidas as condições culturais necessárias para que as representações transcendentes, características da primeira fase da cultura ocidental, dessem lugar às concepções imanentistas do mundo e da vida, e à cabal compreensãodo homem como humanidade, perspectivas que passaram a dominar o pensamento ocidental desde os alvores da modernidade.

No fundo, a lição hegeliana tinha-lhe ensinado que a filosofia, enquanto expressão suprema da cultura, era inseparável da sua história, e que esta era construída pelo combate travado por uma raça que, ao postular como norma de acção um ideal que tende a superar o que existe, se foi afirmando como a única cujo desejo permanente de se ultrapassar encarna o drama da humanidade na busca da consumação do seu próprio destino. Daí que o seu estado anímico fosse um bom barómetro da própria situação da civilização humana. Em 1888, Antero escrevia: "considero este momento como oda grande crise da civilização aríaca, por conseguinte, da humanidade, que a nossa raça representa eminentemente. $\mathrm{O}$ trabalho de 30 séculos produziu este resultado: enorme mas incompleto: o Individualismo; resta saber se a raça que tal produziu terá ainda força e condições convenientes para completar a sua grande obra: juntando àquele primeiro elemento este outro: a harmonia das vontades e a livre organização" $\left({ }^{66}\right)$. Com isto, ele interrogava-se se a raça ariana teria ainda capacidade bastante para superar a crise de organicidade provocada pela sobrevivência, para além da época histórica em que foi necessário, do individualismo. Isto
$\left({ }^{63}\right)$ Idem, Prosas, vol. 3, p. 88.
(44) Idem, ibidem, vol. 1, p. 312.
( $\left.{ }^{65}\right)$ Émile-Louis Burnouf, La Science des Religions, Paris, 1885, p. 99.
${ }^{(66)}$ A. Q., Cartas, vol. 2, p. 882. Os sublinhados são nossos. 
equivalia a saber se, a par do diagnóstico racional da crise, a raça ariana teria ainda vontade $\left({ }^{67}\right)$ para resolver definitivamente a "equação do seu ideal com as suas instituições" $\left({ }^{68}\right)$, solução que teria de apontar para a superação do individualismo e para o cumprimento de um ideal moral de revolução.

Defacto, fazendo a retrospectiva da "evoluçãohistórico-psicológica" da raça ariana, Antero aceitava a existência de um itinerário crescentemente emancipador, em que as visões transcendentes foram dando lugar à representação imanentista do universo e da sociedade. Mas sublinhava - dentro de uma lógica que, em outras filosofias, apresentava a evolução como um percurso de crescente complexização, heterogeneização e individualização(Herbert Spencer) - que, do ponto de vista social, aquela tendência deu corpo a uma estrutura social centrada na definição do indivíduo como uma entidade autónoma e auto-suficiente. Porém, o que, num dado momento, foi adequado à evolução, constituía, numa fase posterior, um elemento perturbador e anacrónico, como a ciência e sobretudo a filosofia estavam a demonstrar. E a manter-se este desajustamento, a civilização ocidental corria o risco de cair num estado anómico, dado que, com o prolongamento crescente do império do individualismo, a sociedade ficava reduzida "ao mínimo de laços e obrigações indispensáveis para não se dissolver materialmente" $\left({ }^{69}\right)$. Em suma: estar-se-ia a viver um tempo de crise orgânica somente comparável à do período da queda do império romano $\left(^{\circ}\right)$, e de onde tanto podia brotar $\mathrm{o}$ apocalipse final como emergir o gérmen da definitiva regeneração.

Se é ainda a partir do seu organicismo sociológico que a ideia de crise aqui surge justificada, importa não esquecer, porém, que, em Antero, as ilações científicas tinham de ser metafisicamente sobredeterminadas. E isto implicava que somente uma filosofia da história de matriz idealista e teleológica podia fundamentar os ritmos da evolução da sociedade. Por outras palavras: cabia à filosofia da história compreender o significado das encarnações temporais do Espírito e a direç̧ão do seu devir. Mas este posicionamento obrigava, igualmente, a responder a esta aparente contradição: se o tempo é ditado por uma
$\left({ }^{67}\right)$ Idem, ibidem, p. 882.
${ }^{68}$ Idem, ibidem, p. 878.
( ${ }^{69}$ Idem, ibidem, p. 882.
( ${ }^{70}$ ) Cf. Idem, ibidem, vol. 2, p. 879. 
finalidade interna, como se justificavam, então, as frequentes irrupções de crises? Pergunta que, na conjuntura, passava por uma outra então muito debatida: quais seriam as relações entre a necessidade histórica (teorizada pelas filosofias oitocentistas da história) e o acaso?

Ao contrário de Oliveira Martins, Antero não aceitou a teoria de Cournot, que definia o acaso como o encontro fortuito de duas séries convergentes, embora reconhecesse ao fortuito um lugar ao nível da fenomenologia do Espírito. Isto é, o necessitarismo somente era válido no horizonte da "história ideal, ou da Filosofia da história" (o que recorda Vico), já que, na sua realização concreta e positiva, a história comportava "todos os azares e fatalidades (mais, pressupõe-nos) inerentes ao mesmo dado do problema da Evolução histórica, que é o movimento do Espírito no meio da Natureza" ${ }^{(1)}$. Por conseguinte, não podia ficar excluída, no campoempíricoda objectivação da historicidade do Espírito, a existência de "crises, lacunas, retrocessos, porquanto a sua necessidade é toda ideal" $\left({ }^{2}\right)$, isto é, é uma necessidade em si e não nas suas múltiplas e imprevisíveis formas de encarnação. Daí as prevençőes anterianas contra o excessivo necessitarismo panlogista de Hegel, embora, nesta dialéctica entre a idealidade e a realidade, o ilógico ou o aparentemente irracional surjam como uma espécie de efeitos da "astúcia" da razão que, no telos do devir, são momentos de negatividade de um processo cujo desfecho já se sabe qual poderá vir a ser: - a realização final da ideia de Bem.

É por isso que a história, exigindo a contradição, se desenvolve, não segundo um ritmo linear ou sob o signo da épica, mas como a objectivação, num tempo elíptico, do drama essencial do próprio Ser, pelo que "a única ideia segura da filosofia da história" é a de demonstrar que todas as contradições, dores, injustiças, guerras ("a guerra, como disse Proudhon..., é a última e mais segura pedra de toque da virtude das nações, ou seja, da sua capacidade de Justiça" $\left({ }^{73}\right)$ ) são momentos necessários do devir $\left({ }^{74}\right)$.
(71) Idem, ibidem, vol. 1, p. 223.
( ${ }^{72}$ ) Idem, ibidem.
$\left({ }^{73}\right)$ Idem, ibidem, vol. 2, p. 923.
$\left({ }^{74}\right)$ Idem, ibidem, vol. 1, p. 192. 
Perante esta visão elíptica do tempo histórico, já não surpreende que, em Antero, como em muitos intelectuais seus contemporâneos imbuídos de historicismo, se detecte como que uma inversão do pensamento mítico em relação ao valor ontológico do presente: o que naquele se traduz numa nostalgia pelas origens primordiais, surge, nas filosofias do devir, como uma protensão para o futuro, sendo este antevisto como promessa de consumação plena do sentido do tempo. Todavia, em ambas as concepções, o presente é sempre entendido em termos de queda e de decadência, isto é, como uma situação de crise (a ideia de crise é inseparável da de decadência), que só uma acção humana, assente numa forte vontade de reconversão espiritual, poderia ultrapassar. $\mathrm{O}$ que, na lógica interna da sua filosofia da história, implicava uma radical regeneração das consciências guiada por normas éticas anti-egoístas e fundantes de um novo consenso social, porque, sem uma nova e forte vontade colectiva, "toda a obra legislatória é vã, pois tudo quanto é orgânico pressupõe um princípio interno ou força vital, único que dá plasticidade às transformaçōes do organismo" $\left({ }^{75}\right)$.

À luz desta exigência, a ideia de revolução não podia ser reduzida a um anelo que, como possibilidade objectiva, estava inscrito na tendência evolutiva da sociedade; era também uma conversão intelectual e volitiva, que devia começar na intimidade de cada eu, e cujo desfecho prometia a inauguração de um novo consenso, porque ela significava, em última instância, "a conclusão necessária da desrazão e do egoísmo universais" $\left({ }^{76}\right)$. E só no contexto desta aspiração se poderia, finalmente, perceber que, aquilo que oliberalismo apresentava como a fase terminal da evolução humana, era tão-só (como a realidade social dos países latinos e particularmente da França sob a III República bem mostrava) a manifestação serôdia da "decomposição democrática, condição passageira mas necessária da profunda revolução social que trabalha toda a Europa" $\left({ }^{7}\right)$. Deste modo, a acção sobre a sociedade não podia ser confundida com os desejos subjectivistas de uns tantos revolucionários, porque teria de radicar numa compreensão objectiva do sentido de evolução do universo e da história, saber que só a ciência e a filosofia poderiam fornecer. Relembre-se: se a ciência, sobretudo as

\footnotetext{
$\left({ }^{75}\right)$ Idem, ibidem, vol. 2, p. 882.

( ${ }^{76}$ ) Idem, ibidem, p. 1014.

$\left({ }^{77}\right)$ Idem, ibidem, vol. 1, p. 507.
} 
ciências sociais, transmitiam uma visão fenomenologica, e, portanto, limitada, das leis sociais, só a metafísica - essa criação da raça ariana - poderia iluminar os fundamentos mais íntimos e últimos de um Ser que, qual "Deus progressivo", só no seu devir se realiza e ascende à consciência de si.

\section{Revolução e Evolução}

Em síntese:para ohistoricismo, a objectivação concreta(Volksgeist) do Espírito Universal era compatível com uma teoria social organicista que tinha na lei da evolução a face científica, logo fenomenológica, da sua diacronia. Com o impacto das teses transformistas, bem como das concepções de Herbert Spencer e de Haeckel, a dimensão evolutiva dos organismos passou a ser transposta para a sociedade. Antero não aceitou dar acriticamente esse passo, porque, na sua opinião, o significado último do evolucionismo só podia ser apreendido mediante uma fundamentação metafísica. Porém, não teve dúvidas de que, nos limites da explicaçã̃o científica, toda a acção sobre a história, que quisesse superar outopismo subjectivista à 1848 , ou o voluntarismoconspirativo à maneira jacobina e blanquista, teria de perceber que, conquanto as sociedades fossem onticamente realidades orgânicas em devir, a sua estrutura objectiva impedia que pudessem ser arbitrariamente revolucionadas. E é a partir desta conclusão que se pode compreender o primeiro nível em que situou o seu entendimento da ideia de revolução, definindo-a como sendo sinónimo de evolução.

Com efeito, em oposição aos socialistas da geração de 48, Antero defendia que as novas ciências sociais ensinavam "a ver a sociedade como um organismo dotado de uma vitalidade propria", cujas "leis não se alteram impunemente; um organismo em que, se tudo se move e se transforma, tudo se move no seu tempo e no seu lugar, conforme as condições internas da sua complexa e delicada existência" $\left({ }^{8}\right)$. Nesta perspectiva, como a ciência permitia cientificar a política, o saber científico tornava absurdo o modelo de "antigo revolucionário, hirto, sistemático, intratável e quimérico", transfor-

$\left({ }^{78}\right)$ Idem, Prosas, vol. 2, pp. 280-281. 
mando-o numa "curiosidade arqueologica" $\left({ }^{79}\right)$. Em alternativa, o novo revolucionário aparecia como "um homem de ciência e de crítica", porque, como escrevia em 1875, a revolução "não pode ser um simples tema de raciocínios abstractos, de declamações e de visionices sentimentais", pelo que só se pode ser verdadeiramente revolucionário "no terreno das realidades, no terreno da observação e da ciência, naquele ponto de vista objectivo, que Proudhon bem definiu em duas palavras - des reformes toujours, des utopies jamais (...). Fora disto haverá utopistas, escolásticos, entusiastas, haverá mártires das suas próprias ilusões, haverá tudo quanto quiserem - menos revolucionários" $\left.{ }^{80}\right)$.

Não espanta, assim, que um dos qualificativos mais frequentes que ele deu da palavra "revolução" tenha sido o de "evolução". De facto, no seu texto mais revolucionário - $O$ que é a Internacional (1871) -, esta definição surge com toda a clareza, já que, no seu entender, o propósito da Internacional seria o de, "evolutivamente, por meio de sucessivas transformações", criar um "novo governo social" ${ }^{\left({ }^{81}\right)}$. E, na apresentação da revista Pensamento Social, retomou esta perspectiva, ao caracterizar o socialismo como uma "evolução revolucionária" $\left.{ }^{82}\right)$, única via que, na sua opinião, estava de acordo com o "ponto de vista da doutrina filosófica da Evolução" $\left({ }^{83}\right)$. E esta indicava, voltamos a repeti-lo com palavras do próprio Antero, que a sociedade não pode "ser transformada se não no sentido [das] suas leis orgânicas e duma maneira orgânica também, istoé, segundo o processo natural por que se transformam todos os seres vivos, por uma luta e gradual substituição de elementos, por um novo equilíbrio de forças, realizado por tentativas, e não bruscamente, revulsivamente" $\left({ }^{84}\right)$.

Ora, se esta posição pretendia demarcar-se das concepções subjectivistas e utópicas, é igualmente verdade que, apesar do seu organicismo, Antero criticou a interpretação da lei da evolução feita pelo monismo materialista e pelo dinamismo mecanicista. Pensamos que esta crítica seria um dos temas fortes do seu ensaio Programa
$\left({ }^{79}\right)$ Idem, ibidem, p. 282.
$\left({ }^{80}\right)$ Idem, ibidem.
( $\left.{ }^{81}\right)$ Idem, ibidem, p. 182. Os sublinhados são nossos.
${ }^{\left({ }^{82}\right)}$ Idem, ibidem, vol. 3, p. 191. Os sublinhados são nossos.
$\left({ }^{83}\right)$ Idem, ibidem, vol. 2, p. 282.
(84) Idem, ibidem, p. 281. 


\section{Política, História e Revolução}

dos Trabalho para as Gerações Novas, nomeadamente no capítulo Cosmos e Evolução, escrito, conforme confessou, com a preocupação de fundamentar o evolucionismo materialista mediante a combinação do devir hegeliano com a dialéctica serial proudhoniana $\left({ }^{85}\right)$. S6 assim o evolucionismo poderia desaguar numa autêntica filosofia do progresso - visto como um crescente aumento qualitativo de Ser, isto é, de espiritualização-, dado que, sem a mediação metafísica, oevolucionismo social convidava à completa naturalização da sociedade (e da consciência) e conduzia à imersão do homem no determinismo fatalista, características igualmente incompatíveis com uma verdadeira filosofia da liberdade. É que, como o conhecimento científico era um saber que se limitava a relacionar fenómenos, a lei da evolução, reduzida aos limites da ciência, ficava cingida ao seu "carácter puramente mecânico e naturalista" ${ }^{86}$ ), isto É, a uma passagem do homogéneo para o heterogéneo, do simples para o complexo, do mesmo para o mesmo, sendo, por isso, incapaz de dar resposta às aspirações íntimas que o homem descobre dentro de si e que o impelem a assumir-se como um ser essencialmente moral.

Perante isto, compreende-se que as limitações de que, segundo Antero, o evolucionismo sociológico (à Spencer) padecia, fossem uma das faces da sua crítica metafísica às pretensões universalistas do naturalismo. Na verdade, apesar de nunca ter explicitado o seu pensamento no que respeita aos elos existentes entre a metafísica e a sociologia, o certo é que, em alguns passos dos seus textos, encontramos a indicação dos malefícios éticos e sociais que resultavam da subordinação da dimensão orgânico-natural das sociedades à sua dimensão espiritual. Num interessante debate epistolar travado com Oliveira Martins em 1873. Antero frisava que "as leis da concorrência (struggle for life) divisão do trabalho, etc., não podem ser aplicadas ao mundo social senão nos limites em que esse mundo pertence à ordem orgânica, e não absolutamente, porque além da ordem orgânica há no mundo social outra coisa e coisa muito superior que é o espírito. Por isso essas leis $1^{\circ}$ aplicam-se só parcialmente: $2^{\circ}$ são, na sua aplicação, dirigidas e dominadas pelo espírito para os seus fins superiores" $\left({ }^{87}\right)$.

$\left({ }^{85}\right)$ Idem, Cartas, vol. 1, pp. 227, 231. Cf. Fernando Catroga, A Metafísica Indutiva de Antero de Quental, pp. 494-99.

$\left({ }^{86}\right)$ A. Q., Cartas, vol. 1, p. 180.

${ }^{87}$ Idem, ibidem, pp. 230-231 Os sublinhados são nossos. 
Quer isto dizer que só uma filosofia do Espírito poderia iluminar o sentido do evoluir social e das suas leis, pois, como escreveu nas Tendências Gerais, "no mundo da consciência dissolvem-se todas as leis naturais e sociais na única lei moral" $\left.{ }^{88}\right)$. Consequentemente, só com a subordinação da ciência à moral - que só a metafísica poderia fundamentar-a evolução mecânica podia aparecer como a objectivação fenomenológica do devir, em que a passagem da realidade inferior à realidade superior implicava um aumento qualitativo de ser, um quid novo, e, ao mesmo tempo, se podia justificar a evolução cósmica como um processo de crescente espiritualização, logo, como um verdadeiro progresso. Por outras palavras: só a mediação metafísica possibilitaria a ultrapassagem do determinismo característico da legalidade natural e abriria a consciência à compreensão de que "a evolução não é apenas uma complicação crescente de forças elementares [comoem H. Spencer]: é um alargamento de ideias, istoé, de existência verdadeira. E se o ideal supremo, que a tudo atrai, para que tudo gravita, é razão, vontade pura, plena liberdade, a evolução só será perfeitamente compreendida definindo-se como a espiritualização gradual e sistemática do universo" $\left.{ }^{89}\right)$. Assim, aquilo que na ordem do mundo inorgânico e orgânico se manifesta inconscientemente, só pela consciência poderá saber de si. Daí que, mesmo nas suas formas mais rudes de organização social, a sociedade (e a história) apareçam como o palco da liberdade, porque a sociedade, cujo ideal é a justiça e não a necessidade, vai gradualmente aproximando-se do seu fim (ideal-tipo). E este não pode ser diferente da essência do ente que a pensa, logo, da essência espiritual do próprio homem.

\section{Revolução como Revelação}

Ora, se tudo isto torna coerente que a revolução, enquanto realização da proudhoniana ideia de Justiça - objectivação sócio-política da ideia metafísica de Bem-, seja sinónimo da evolução, o que agora ficou sugerido apresenta a história como o teatro em que essa realização

\footnotetext{
${ }^{(88)}$ Idem, Prosas, vol. 3, p. 131.

(89) Idem, ibidem, p. 128.
} 
dramaticamente se encena num jogo infinito (e narcísico) gizado por um Ser que peregrina no tempo em busca da consciência de si mesmo. E é neste contexto que devemos entender uma outra definição que Antero deu de revolução: "Uma das muitas traduções livres da palavra revolução", escreveu em 1868, "é esta: revelação. No momento da crise apaixonada, as forças mais íntimas, os elementos mais profundos da sociedade revolvida nos seus abismos, agitando-se por chegar a claridade, sobem até à superfície e mostram-se à luz do dia com uma energia, uma verdade irresistíveis. É uma revelação" $\left({ }^{90}\right)$ metaforicamente análoga à força telúrica típica das emanações essenciais. E foi ainda desta imagem que Antero se serviu para caracterizar a sua reacção perante a Comuna de Paris, "sublime na sua cegueira, como um elemento, uma força natural (...). A crítica, que se aprende na escola do senso comum, deve ser posta de parte em face destas coisas gigantescas e tenebrosas por onde a história se revela de séculos a séculos pelo seu lado mais sublime mas também mais obscuro - a fatalidade" $\left.{ }^{91}\right)$. E, se esta irrupção foi inevitável até ao período em que o homem não teve a possibilidade de tornar transparente o sentido da história, e esteve fatalmente a ele subjugado, o conhecimento não só científico, mas, sobretudo, de raiz metafísica, dava, finalmente, o poder para a humanidade se apropriar autonomamente do seu destino, transformando a revolução (e o fatalismo da história) num pacífico processo evolutivo, porque racionalmente controlado. Em suma: a gnose sobre o sentido da história iria finalmente mostrar que "revolução não quer dizer guerra, mas sim paz: não quer dizer licença, mas sim ordem, ordem verdadeira pela verdadeira liberdade. Longe de apelar para a insurreição, pretende preveni-la, torná-la impossível: só os seus inimigos, desesperando-a, a podem obrigar a lançar mão das armas. Em si é, um verbo de paz, porque é o verbo humano por excelência" ${ }^{{ }^{92}}$ ).

Significa isto que os imperativos da história irrompem com um grau de surpresa e de violência proporcional ao que a consciência humana sabe deles. $O$ que, desde logo, levanta a necessidade de se inteligir 0 lugar da acção humana no transcurso objectivo do tempo, questão tanto mais importante quanto se conhece a crítica que a geração de Antero fez
$\left({ }^{90}\right)$ Idem, ibidem, vol. 2, p. 50.
(11) Idem, Cartas, vol. 1, pp. 117-118. Os sublinhados são nossos.
(2) Idem, Prosas, vol. 2, p. 139. 
Quer isto dizer que só uma filosofia do Espírito poderia iluminar o sentido do evoluir social e das suas leis, pois, como escreveu nas Tendências Gerais, "no mundo da consciência dissolvem-se todas as leis naturais e sociais na única lei moral" $\left.{ }^{88}\right)$. Consequentemente, só com a subordinação da ciência à moral - que só a metafísica poderia fundamentar-a evolução mecânica podia aparecer como a objectivação fenomenológica do devir, em que a passagem da realidade inferior à realidade superior implicava um aumento qualitativo de ser, um quid novo, e, ao mesmo tempo, se podia justificar a evolução cósmica como um processo de crescente espiritualização, logo, como um verdadeiro progresso. Por outras palavras: só a mediação metafísica possibilitaria a ultrapassagem do determinismo característico da legalidade natural e abriria a consciência à compreensão de que "a evolução não é apenas uma complicação crescente de forças elementares [comoem $H$. Spencer]: é um alargamento de ideias, istoé, de existência verdadeira. E se oideal supremo, que a tudo atrai, para que tudo gravita, é razão, vontade pura, plena liberdade, a evolução só será perfeitamente compreendida definindo-se como a espiritualização gradual e sistemática do universo" ${ }^{89}$ ). Assim, aquilo que na ordem do mundo inorgânico e orgânico se manifesta inconscientemente, só pela consciência poderá saber de si. Daí que, mesmo nas suas formas mais rudes de organização social, a sociedade (e a história) apareçam como o palco da liberdade, porque a sociedade, cujo ideal é a justiça e não a necessidade, vai gradualmente aproximando-se do seu fim (ideal-tipo). E este não pode ser diferente da essência do ente que a pensa, logo, da essência espiritual do próprio homem.

\section{Revolução como Revelação}

Ora, se tudo isto torna coerente que a revolução, enquanto realização da proudhoniana ideia de Justiça - objectivação sócio-política da ideia metafísica de Bem-, seja sinónimo da evolução, o que agora ficou sugerido apresenta a história como o teatro em que essa realização

\footnotetext{
$\left({ }^{83}\right)$ Idem, Prosas, vol. 3, p. 131.

${ }^{89}$ Idem, ibidem, p. 128.
} 
dramaticamente se encena num jogo infinito (e narcísico) gizado por um Ser que peregrina no tempo em busca da consciência de si mesmo. E é neste contexto que devemos entender uma outra definição que Antero deu de revolução: "Uma das muitas traduções livres da palavra revolução", escreveu em 1868, "é esta: revelação. No momento da crise apaixonada, as forças mais íntimas, os elementos mais profundos da sociedade revolvida nos seus abismos, agitando-se por chegar à claridade, sobem até à superfície e mostram-se à luz do dia com uma energia, uma verdade irresistíveis. É uma revelação" $\left({ }^{90}\right)$ metaforicamente análoga à força telúrica típica das emanações essenciais. E foi ainda desta imagem que Antero se serviu para caracterizar a sua reacção perante a Comuna de Paris, "sublime na sua cegueira, como um elemento, uma força natural (...). A crítica, que se aprende na escola do senso comum, deve ser posta de parte em face destas coisas gigantescas e tenebrosas por onde a história se revela de séculos a séculos pelo seu lado mais sublime mas também mais obscuro - a fatalidade" ( $\left.{ }^{91}\right)$. E, se esta irrupção foi inevitável até ao período em que o homem não teve a possibilidade de tornar transparente o sentido da história, e esteve fatalmente a ele subjugado, o conhecimento não só científico, mas, sobretudo, de raiz metafísica, dava, finalmente, o poder para a humanidade se apropriar autonomamente do seu destino, transformando a revolução (e o fatalismo da história) num pacífico processo evolutivo, porque racionalmente controlado. Em suma: a gnose sobre o sentido da história iria finalmente mostrar que "revolução não quer dizer guerra, mas sim paz: não quer dizer licença, mas sim ordem, ordem verdadeira pela verdadeira liberdade. Longe de apelar para a insurreição, pretende preveni-la, torná-la impossível: só os seus inimigos, desesperando-a, a podem obrigar a lançar mão das armas. Em si é, um verbo de paz, porque é o verbo humano por excelência" ${ }^{{ }^{92}}$ ).

Significa isto que os imperativos da história irrompem com um grau de surpresa e de violência proporcional ao que a consciência humana sabe deles. $O$ que, desde logo, levanta a necessidade de se inteligir 0 lugar da acção humana no transcurso objectivo do tempo, questão tanto mais importante quanto se conhece a crítica que a geração de Antero fez
$\left({ }^{90}\right)$ Idem, ibidem, vol. 2, p. 50.
(91) Idem, Cartas, vol. 1, pp. 117-118. Os sublinhados são nossos.
$\left({ }^{92}\right)$ Idem, Prosas, vol. 2, p. 139. 
não só ao providencialismo como, no pólo contrário, à versão individualista e carlyliana da ideia de "grande homem". Recorde-se que este passou a ser visto, não como o auto-suficiente criador dos acontecimentos históricos, mas tão-somente como o encarnador do "espírito de uma época", espécie de medium capaz de dar voz às exigências do seu tempo; seria, em suma, um representative man, ou melhor, a objectivação de uma vontade colectiva que, nas épocas já passadas, teve uma inconsciente tradução cósmica e histórica, mas que, finalmente, estaria na iminência de ascender a Ideia e de se realizar como prática social $\left({ }^{93}\right)$.

Tudo isto sugere que a perspectiva que aqui estamos a privilegiar incide sobre a visão da história que decorre da sua metafísica, explorando, aliás, uma via indicada pelo próprio Antero, ao defender, em coerência com a sua interpretação do hegelianismo, que "a filosofia da história encerra em si quase a filosofia toda, e entendo que o verdadeiro e definitivo sistema que este nosso século tem de construir deve ser essencialmente histórico. Quero dizer que sendo a história a manifestação do desenvolvimento da natureza humana, esse desenvolvimento é essencialmente uma revelação e um símbolo concreto dessa natureza, onde ela, viva, activa e não abstracta, se expande e manifesta. Daqui concluo", rematava Antero em 1874, "que o em si das ideias metafísicas, cosmológicas, sociais e morais deve sobretudo revelar-se na história dessas ideias mais do que na razão abstracta. A lógica da Evolução pede que assim seja" $\left({ }^{94}\right)$. Consequentemente, não admira que, nele, tal como no historicismo moderno, a assunção da história como o palco em que a natureza humana se objectiva, ou melhor, como uma antropofania, seja correlata da problemática das filosofias da "morte de Deus" e, como estas, enalteça a auto-suficiência do universo e do homem. Por isso, a verdadeira filosofia, mais do que um sistema abstracto e acabado, devia resumir-se à apresentação da própria "ideia histórica da humanidade, perseguida, entrevista, esquivada, pressentida através de todos os sistemas, de todas as religiões, de todas as revoluções" $\left({ }^{95}\right)$.

Esta concepção de um tempo histórico movido pela espontaneidade

${ }^{(93}$ ) Sobre esta questão, veja-se Fernando Catroga, A Militância Laica e a Descristianização da Morte em Portugal (1865-1911), 2 vols., Coimbra, 1988, pp. 891-898.

( $\left.{ }^{94}\right)$ A. Q., Cartas, vol. 1, p. 247. Os sublinhados são nossos.

${ }^{(95)}$ Idem, ibidem, p. 226. 
imanente do universo - a espontaneidade é uma ideia-chave no pensamento de Antero - e visto como a objectivação civilizacional do dinamismo cósmico apontava para a colocação da humanidade no vertice da pirâmide ${ }^{(96}$ ) construída pela escalada ascendente do Ser porque só no homem este poderá assumir consciência de si. No fundo, Antero dava expressão metafísica ao enaltecimento da humanidade que tanto empolgou a sua geração. Eça falou mesmo no aparecimento de uma espécie de culto a "Madame Humanidade", atitude que, em Teófilo Braga e nos republicanos em geral, se traduziu na popularização de uma "religião cívica" de inspiração positivista que teve nas comemorações de Camões (1880) a sua primeira grande manifestação colectiva $\left({ }^{97}\right)$. Naturalmente, Antero não podia concordar com esta versão cultualista do humanismo, pelo que via o novo Deus de Téfilo nestes termos: "a tal Humanidade, que ele agora adora e para cujo culto pretende seduzi-lo [Fernando Leal], precisava, antes de adorada, ser definida. É verdade que um Deus definido perde a graça e já não presta. Oh! Téfilo, grande ateu, que nasceste para irmão do Santíssimo! O Inconsciente prega às vezes destas peças aos pobres mortais" $\left({ }^{98}\right)$. É que, em Antero, a "expulsão" ou "exílio" de Deus - "Dieu, c'est le mal" ensinava o seu mestre Proudhon $\left({ }^{99}\right)$ - deu-se numa subjectividade que ele mesmo definiu como sendo "naturalmente religiosa" $\left({ }^{100}\right)$ e, por isso, existencialmente carente de encontrar um fundamento que, para além do evolucionismo mecânico ou das idolatrias exteriores da religião da humanidade, desse um sentido à vida individual e colectiva. E a chave deste enigma não podia ser dada pela ciência (como Teófilo acreditava), pois só a metafísica a poderia fornecer.

Sintetizando, pode dizer-se que o lugar do Deus-Pessoa do Cristianismo, transcendente e criacionista, foi ocupado pela substância, causa sui, como em Espinosa, mas agora dialecticizada e temporalizada (como em Leibniz, Schelling, Hegel e Hartmann), passando a ser

${ }^{(6)}$ Idem, Prosas, vol. 3, p. 129.

${ }^{97}$ Cf. Fernando Catroga, ob. cit., vol. 2, p. 891 ss.

${ }^{98}$ A. Q., Cartas, vol. 2, p. 899. E foi ainda neste contexto de crítica à religião positivista da humanidade que, ironicamente, Antero qualificou as manifestações públicas em honra de Camões, istoé, as festas do centenário, como sendo as "festas do santanário". (Idem ibidem, vol. 1, p. 501).

$\left({ }^{99}\right)$ Cf. P.-Joseph Proudhon, Système des Contradicitions Économiques ou Philosophie de la Misère, t. 1, 1923, p. 389.

(100) A. Q., Cartas, vol. 2, p. 834. 
uma Potência passível de múltiplas e espontâneas actualizações. E este processamentoobjectiva-se numa realidade monadologicamente hierarquizada, de acordo com a capacidade que cada degrau tem para ascender à consciência de si. Assim sendo, o ensinado pela filosofia da natureza só se esgota na filosofia da história. E aqui, se Antero é hegeliano, não deixa de retomar uma tradição que, remontando a algum naturalismo do Renascimento (Paracelso, Boehme, Teologia Germanica) $\left({ }^{101}\right)$, passa igualmente por Herder, e tem a sua melhor expressão em Schelling, o grande sistematizador da matriz da filosofia romântica da natureza. Com efeito, em Schelling, esta é caracterizada de um modo dinâmico (em contraste com a visão meramente geométrica do panteísmo de Espinosa) e definida, simultaneamente, em termos biológicos e psicológicos. O seu dinamismo parte da realidade inferior para ascender a graus superiores cuja consumação final é o homem, num processo que é comandado pela luta entre dois princípios - um consciente e outro inconsciente. E foi neste horizonte que Schelling procurou mostrar a lentidão do desenvolvimento da consciência nos diferentes graus da natureza até alcançar, no homem, plena consciência de si, estádio que, por sua vez, é o ponto de partida de um novo processo: - o desenvolvimento da cultura e da história $\left({ }^{102}\right)$.

Também em Antero, a substância, sendo causa de si, se vai materializando na diversidade pluridimensional da realidade de um modo inconsciente e segundo uma sucessão qualitativa que culminou na emergência da humanidade (e da história) como o grau supremo em que ela terá a possibilidade de se realizar em plenitude, porque "a obra tão maravilhosa começada pelo inconsciente só pela consciência podia ser levada a cabo" ( $\left.{ }^{103}\right)$. E, apesar de ter tido um conhecimento mais profundo das filosofias do inconsciente através de um diálogo mais directo com a interpretação de um discípulo pessimista de Hegel e de Schelling (Eduardo de Hartmann), o certo é que não aderiu às ilações niilistas defendidas por esteúltimo. Éque, para Hartmann, o Inconsciente

(101) Recorde-se que Antero, como confessa na sua carta auto-biográfica a W. Storck, meditou profundamente sobre este tex to anónimo, saído da "escola" de Mestre Eckhart. Sobre a influência deste livro no pensamento anteriano, veja-se Fernando Catroga, $A$ ideia de evolução em Antero de Quental, pp. 382-384.

$\left({ }^{102}\right)$ Paul Tillich, La Naissance de l'Esprit Moderne et la Théologie Protestante, Paris, 1972, p. 184.

$\left({ }^{103}\right)$ Idem, Prosas, vol. 3, p. 129. 


\section{Política, História e Revoluçao}

constituía um fundo nocturno de onde brotava a vida, a consciência e a história. E embora aceitasse, como Antero, o valor relativo das teses evolucionistas e transformistas, criticou Darwin por este não ter percebido que, se a teleologia do Ser exige o mecanicismo, o mecanicismo é impossível sem a teleologia $\left({ }^{104}\right)$. Mas, a seu ver, o finalismo inerente à evolução não desaguava no ideal perfectibilista típico do Iluminismo, pois a conquista acrescida do progresso só contribuía para aumentar a "consciência infeliz". Daí que a tradução histórica do inconsciente culminasse no pessimismo, pelo que teria sido mais razoável que o universo nunca tivesse existido $\left({ }^{105}\right)$.

Ora, nada nos textos anterianos de cariz mais filosófico nos autoriza a semelhante conclusão. A compreensão da finalidade imanente ao devir cósmico e histórico mostrava que o homem, nem era um ser isolado, nem uma "paixão inútil", porque a sua ascensão à verdadeira sagesse revelava-o em comunhão cordial com todo o universo. E se, como em Schelling, não colocava um ideal estético no ponto de chegada da consumação da humanidade, é porque, apesar da sua devoção à arte, só a filosofia, como em Hegel, poderia revelar a verdade e mostrar a finalidade matricialmente ética que comanda o devir. Por isso, não tremia, como Pascal, perante a frieza dos espaços infinitos, isto é, "não sentia aquela impressão de vacuidade e morte, aquela tristeza fúnebre, que o mundo fatal e eternamente mudo do materialismo lhe infundia". É que, ascendendo à verdade, o espírito humano sentiria "palpitar nas coisas o que quer que é análogo à sua essência",e ohomem, "isolado como no vértice de pirâmide prodigiosa", entraria, finalmente, "em comunicação com a mole imensa que o suporta"; aí, ele, "já não é o enigma incompreensível, desesperador, que a si mesmo parecia, quando olhando em volta via em tudo a negação do seu pensamento, do seu ideal, da sua essência: pelo contrário, ele próprio é que é agora a chave do enigma universal; só ele conhece a causa e o fim de tudo, e esse segredo sublime é a sua verdade mais íntima, e o seu mesmo ser" $\left({ }^{106}\right)$.

${ }^{\left({ }^{104}\right)}$ Cf. Eduard v. Hartmann, Le Darwinisme, ce qu'ily a de vrai et de faux dans cette théorie, Paris, 1894 (a edição alemã é de 1875).

$\left({ }^{105}\right)$ Idem, Philosophie de l'Inconscient, vol. 2, Paris, 1877, p. 362.

$\left({ }^{106}\right)$ A. Q., Prosas, vol. 3, p. 129. 


\section{FILOSOFIA DA HISTÓRIA E CRISTIANISMO}

Perante esta conclusão, pensamos não ser abusivo procurar defender que também o evolucionismo anteriano deve ser inscrito no processo secularizador da visão judaico-cristã do tempo característico do historicismo moderno $\left({ }^{107}\right)$. A história, qual "calvário do Espírito Absoluto", é a objectivação temporal de um Sujeito omnipresente e eterno que lhe confere uma finalidade e fim imanentes, isto é, constitui a desenvolução e revelação de um Deus "abscôndito", que só através do saber humano será em si, por si e para si. De facto, também para Antero, "as revoluções, os cultos, os sistemas, as filosofias" não são "princípios exteriores, que dominem a história, de cima, da altura de suas verdades, determinando os sentimentos, os desejos, as crenças, a vida enfim. Pelo contrário, são apenas evoluções de um princípio interior, que as cria e destrói, e faz o novo templo com as ruínas do templo antigo (...) O Deus da Humanidade é o mesmo homem: e o seu ideal a religião da Vi$d a^{\prime \prime}\left({ }^{108}\right)$. E, com esta tese, ele traduzia em português uma das facetas mais fortes da leitura secularizada do problema de Deus, a que Feuerbach deu expressão filosófica, ao defender a definitiva construção antropológica da nova visão do mundo e ao sustentar que o verdadeiro infinito se encontra no "homem genérico" (Homo homini deus est) $\left.{ }^{109}\right)$. Por outras palavras: pode afirmar-se que, em Antero, encontramos uma interessante síntese directa ou indirectamente tributária da leitura hegeliana e da concepção de Feuerbach do problema de Deus, já que, nele, tal como em Hegel, Deus tornou-se necessariamente homem para se elevar à consciência de si; mas, como em Feuerbach, esta mediação é correlata do entendimento de Deus como projecção da consciência que o homem tem da sua própria infinitude $\left({ }^{110}\right)$.

$\left({ }^{107}\right)$ Para uma visão da problemática actual do debate acerca da matriz judaico-cristã do fenómeno da secularização típico da modernidade, veja-se Miguel Baptista Pereira, Modernidade e Secularização, Coimbra, 1990, pp. 47-63. Para uma visão das incidências histórico-políticas da apropriação secularista dessa herança, leia-se Jean-Pierre Sironneau, Sécularisation et Réligions Politiques, La Haye-Paris-New York, 1982.

$\left({ }^{108}\right)$ A. Q., Prosas, vol. 1, p. 266.

${ }^{109}$ Cf. M. Xhaufflaire, Feuerbach et la Théologie de la Sécularisation, Paris, 1970.

(110) Cf. Paul Tillich, ob. cit., p. 175 ss. 
Por tudo isto, não é difícil detectar na posição de Antero um evidente fundo bíblico, inserido, porém, num horizonte imanentista e secularizado. Não admira. Ele também foi particularmente receptivo às hermenêuticas racionalistas - filológicas e filosóficas - da Bíblia (Renan, Havet, Strauss), e os seus textos reflectem a visão do fenómeno religioso como sendo, em última análise, uma projecção invertida da essência da humanidade, tese avançada por Feuerbach, mas que, muitas vezes de um modo mitigado, encontramos em boa parte da literatura romântica francesa que influenciou a formação intelectual da sua geração (Proudhon, Quinet, Michelet ( $\left.{ }^{111}\right)$ ). Por outro lado, importa ainda ressaltar que ele desde cedo perfilhou uma periodização do devir, que mais tarde incorporará nas Tendências Gerais da Filosofia na segunda metade do século XIX, em que, na perspectiva de uma leitura ideal da história, o advento da modernidade é caracterizado como uma necessária passagem das concepções transcendentes do universo (de que o cristianismo constituiu a expressão suprema) para a definitiva concepção imanente. $\mathrm{E}$, em termos das alterações das capacidades cognitivas do homem, este trânsito implicou que o domínio da imaginação e do sentimento fosse ficando, na fase imanentista, finalmente subordinado ao crivo da razão crítica $\left({ }^{112}\right)$.

É neste contexto historicista que temos de entender a aparentemente paradoxal atitude de Antero em relação ao cristianismo e à figura de Cristo. A irreversibilidade da história ditava que o cristianismo, enquanto uma das expressões concretas da objectivação do Espírito num dado momento do seu percurso, estivesse inexoravelmente condenado a ser ultrapassado em nome das exigências do cumprimento do finalismo imanente à história. Daí que a modernidade tivesse podido decretar que "o Cristianismo morreu totalmente: em corpo e em alma. Não é só a lenda cristã que a razão moderna rejeita; é o espírito cristão, o sentir cristão, tudo. Cristianismo, politeísmo, Jeovismo, tudo isso foram andaimes apenas duma construção moral cuja forma já se deixa ver claramente" $\left({ }^{113}\right)$. A ser assim, era discussão menor o debate acerca da verdade histórica da existência de Cristo, como era errado

('1') P. Bénichou, Le Temps des Prophètes. Doctrines de l'Âge Romantique, Paris, 1977.

(112) Cf., A. Q. Cartas, vol. 1, pp. 222-223; vol. 2, p. 918.

(113) Idem, ibidem, vol. 1, p. 245. 
tentar interpretar a religião cristã através da relevação da sua biografia (como, acusava Antero, Renan tinha feito em Vie de Jesus). É que, na lógica da mediação das filosofias do Espírito, isto é, na linha das hermenêuticas de Hegel, Schelling e das primeiras obras de Strauss e da escola de Tübingen, mediatizada pela centração antropológica inaugurada por Feuerbach, Cristo devia ser interpretado como um símbolo que exprimia melhor do que qualquer outro o princípio da Vida e, portanto, do devir universal e humano $\left({ }^{114}\right)$. Deste modo, constituía uma contradição interpretá-lo como sendo Filho de Deus, atitude só justificável para o período em que dominaram as representações transcendentes, mas incompatível com a interpretação racional e imanente exigida pela maturidade espiritual dos tempos modernos. E esta, segundo Antero, apresentava Jesus como um "símbolo, ideia, princípio de vida espiritual", ou melhor, como "princípio" e "ideia pura de vida", pelo que, defender "um Cristo personificado, idolatrado e por isso desvirtuado", seria esquecer que " $a$ vida (princípio ideal, espiritual) não pode ser alguém (uma pessoa, um indivíduo limitado)" (115).

Neste horizonte, o seu significado último só poderia ser apreendido dentro dos quadros continuístas típicos do historicismo de matriz hegeliana (embora preparados pela própria concepçãobíblica do tempo) - o melhor do passado da humanidade foi o momento precursor do advento de Cristo. Com efeito, o cristianismo prolongava e elevava a um grau de maior espiritualidade (ao rei vindicar uma maior autonomia da consciência) o projecto da cultura ocidental (indo-europeia) que teve na Grécia a sua primeira grande afirmação filosófica; mas era, também, o passado de um futuro que irá realizar aquilo que, apesar de um modo transcendente, o melhor da sua mensagem já havia anunciado. Em suma: Deus passou a habitar entre os homens, e Cristo devia ser compreendido como o símbolo profético da consumação do sentido último da história.

Não admira. De certo modo, pode dizer-se que a tarefa da metafísica ocidental consistiu em transferir Deus da transcendência para a imanência do universo e da história. E jáo jovem Antero escrevia que,

${ }^{(114)}$ Sobre esta interpretação do valor simbólico da figura de Cristo na filosofia idealista alemã, veja-se Paul Tillich, ob. cit., pp. 171-175.

(115) Idem, ibidem, vol. 2, pp. 940-941. 
na modernidade, isto é, "hoje, Jehová deixou enfim as alturas e habita modestamente entre os homens", juízo que pressupõe o entendimento da história como um percurso investido da finalidade intrínseca de, paulatinamente, ir anulando a distância que separa o estádio da sua concretização do fim imanente que a move desde o início dos tempos. E é esta perspectiva que faz com que ela seja, em última análise, uma teogonia, ou melhor, uma epopeia antropofânica (dramática, em Antero) que os homens vão construindo (Vico); seja, em suma, uma espécie de missa sobre o mundo no decorrer da qual se dá, não a transubstanciação do pão em carne e do vinho em sangue, mas a crescente afirmação da essencial universalidade da humanidade tornada, finalmente, pai de Deus, ou melhor, pai de si mesma. Com efeito, se "o cristianismo criou a humanidade (no grande e verdadeiro sentido da palavra)", "foi a humanidade toda que o criou a ele" $\left({ }^{116}\right)$, pois, como Antero lembrava em 1873, "mais de 100 anos antes de Platão já Pitágoras dizia: 'o homem é a medida de todas as coisas', o grande princípio que há-de fecundar Vico, e Kant e Hegel, e todos nós" ( $\left.{ }^{117}\right)$. E este antropocentrismo também constituía o significado último do cristianismo, desde que esta religião fosse interpretada como o símbolo da unidade humana: "no dia em que Jesus se chamava a si Cristo, nesse dia deixava de ser judeu para se materializar homem" $\left({ }^{118}\right)$. Quer isto dizer que encontramos em Antero uma das características que estão na génese das filosofias modernas da história e do seu fundo secular e prometeico. Estas nasceram a partir do momento em que, no pensamento ocidental, se deu uma revolução coperniciana decisiva: em vez de se continuar a fazer girar o mundo à volta de Cristo, começou-se a fazer girar Cristo à volta do homem e do mundo $\left({ }^{119}\right)$.

A ser assim, a leitura da reinversão das projecções religiosas exigia que, mais do que como uma teofania, a história fosse entendida como uma antropofania, porque, como mostrava o sentido emancipador do seu devir, "a estátua ideal da Fé humana achou enfim o pedestal de mármore imaculado onde se firmem seus pés divinos - a consciên-

(116) Idem, Prosas, vol. 1, p. 259.

(117) Idem, Cartas, vol. 1, p. 217.

(118) Idem, Prosas, vol. 1, p. 260.

(119) Cf. Jean Brun, Philosophie de l'Histoire. Les Promesses du Temps, Paris, 1990, pp. 120-121. 
cia da nobreza do destino do homem, a revelação da sua mesma divindade" $\left({ }^{120}\right)$. Afinal, os deuses, em vez de ahistóricos criadores de tudo, são criações do homem e, portanto, entes condenados à corrupção do tempo e ao relativismo da inexorável, irreversível e infinita marcha da história em busca da concretização do seu ideal. Isto é, também as divindades "morrem, se sucedem e transformam", enquanto o homem, "que os criara para perder cá a incerteza do seu transitório destino, o homem, o seu coração, o seu ideal sobrevive-lhes, e é ele que parece eterno ao pé desses absolutos passageiros!" $\left({ }^{121}\right)$; e é-o porque, em última análise, a essência do Espírito mais não é do que a essência do proprio homem.

A esta luz, por maior relevo que se dê ao significado do aparecimento da Anunciação, é um facto que a consciência histórica moderna, com a sua tendência secularizadora, eliminou a fé cristã no Acontecimento absoluto, embora tenha explicitado a irreversibilidade do tempo já pressuposta pelo Genesis e confirmada pela Encarnação, e tenha visto, na linha da escatologia judaico-cristã, o passado como preparação e o futuro como consumação $\left({ }^{122}\right)$. Todavia, as expectativas de salvação - as filosofias da história são também promessas de salvação colectiva - começaram a ficar cada vez mais cingidas a um horizonte imanentista e terreno, e a serem comandadas por uma teleologia impessoal fundante de uma ideia de história vista como um percurso de crescente espiritualização, ou melhor, como uma espécie de Evangelho Eterno (Joaquim de Fiori, Lessing) que, simbolicamente, objectiva e exprime a "essência pura e última do homem, e até de todas as coisas, mas só no homem tornada consciente e dotada de voz" $\left({ }^{123}\right)$.

A partir do que ficou exposto, há que perguntar se as preocupações com a busca de sentido - para a sua vida e para a história - não sobredeterminaram o modo como Antero definiu o fundamento substitutivo do Deus-Pessoa, concretizando-o como sendo análogo à alma humana, isto é, como actividade espiritual que, como tende para a realização do Bem, saiu da "imobilidade do símbolo inalterável" ( $\left.{ }^{124}\right)$

\footnotetext{
$\left.{ }^{120}\right)$ A. Q., Prosas, vol. 1, p. 261. Os sublinhados são nossos.

(121) Idem, ibidem, p. 263.

(122) Cf. Karl Löwith, O Sentido da História, Lisboa, 1991, p. 187.

(123) A. Q., Cartas, vol. 2, p. 802.

(124) Idem, Prosas, vol. 2, p. 25.
} 
e fez-se "Vida", objectivando-se pampsiquisticamente(Michelet, Leibniz) como um "Deus progressivo", o qual, por sua vez, mais não é do que uma insciente e inconsciente manifestação de uma essência cuja realização exige o tempo (e a história), porque só o homem a pode conscientemente apreender como Ideia e como Ideal. É assim compreensível que a história seja a explicitação do Logos (do Verbo), espécie de revelação (e revolução) permanente de si; seja, em suma, uma teodiceia, que é, em última análise, uma antropodiceia. Compreende-se. É que já o iluminismo tinha feito da história a encarnação progressiva da razão universal divinizada, enquanto o romantismo alemão a viu como o caminho pelo qual o homem poderá aproximar-se do seu modelo. A história tornou-se, assim, na verdadeira mãe do Ser $\left({ }^{125}\right)$, e a humanidade é convidada a construir esse devir criador que, no fundo, é ela mesma construindo-se a si própria, pois, segundo "o grande princípio de Vico - o homem é o seu mesmo criador" $\left.{ }^{126}\right)$.

Como tem sido sobejamente assinalado, as filosofias da história acabam por ser historizações e secularização da Trindade Cristã. Deus, o Absoluto, o Mundo foram sintetizados e dinamizados numa (e por uma) teogonia que $e$, simultaneamente, uma cosmogonia. E, em termos hegelianos, o Absoluto (o Pai) não é outro que o Weltgeist, o Espírito do mundo fundador de todas as coisas. O Espírito Santo manifesta-se no Zeitgeist, o Espírito do tempo, enquanto o Volksgeist surge como a sua encarnação mais concreta em que o indivíduo se insere. E esta perspectiva sugere que a realização da história se torna equivalente no que, em termos de Joaquim de Fiori, se poderá chamar o definitivo advento da idade do Espírito. E já Schlegel dizia que "o desejo revolucionário de realizar o Reino de Deus é o ponto flexível de uma educação progressista e o princípio da história moderna" ${ }^{127}$ ). É que a revolução, prometida pelos joaquimistas dentro de um horizonte escatológico e com referência a uma vida monástica perfeita, foi retomada pelas filosofias da história da modernidade em termos de um processo que apontava para a realização do reino do Espírito na Terra.

\footnotetext{
${ }^{(25)}$ Idem, ibidem, vol. 1, p. 267.

${ }^{(126)}$ Cf. Jean Brun, ob. cit., p. 132.

(127) In Karl Löwith, ob. cit., p. 198.
} 
É este o optimismo histórico que encontramos em Lessing, Fichte, Schelling e Hegel, bem como nas versões mais positivistas e materialistas do historicismo oitocentista. $\mathrm{E}$, dadas as afinidades electivas de Antero com o idealismo objectivo alemão, também não deve surpreender que o seu finalismo histórico aponte para a promessa do advento da definitiva vitória do Espírito ${ }^{128}$ ).

De facto, também o indivíduo espelhava a unidade triádica essencial, pois, se "a alma da humanidade" está "em cada homem", na humanidade está "a alma inteira do mundo" $\left({ }^{129}\right)$. E é esta analogia que fundamenta a certeza de que "o Deus da Humanidade é o mesmo homem" $\left({ }^{130}\right)$ que, ao realizar-se no tempo, tem de agir de modo a conseguir a crescente espiritualização do Ser, construindo a história como quem escreve o Livro definitivo, qual Bíblia que "tem brancas as últimas páginas, para que lhe possa cada geração nova escrever lá o verso de oiro de cada novo Evangelho que se revele" $\left({ }^{131}\right)$.

Por outras palavras: a objectivação temporal do Espírito é uma totalidade evoluente que se revela nos indivíduos e na "alma dos povos" - essa entidade quase mítica que Antero via exemplarmente expressa, para o caso francês, na obra de Michelet - para os ultrapassar na apaixonada busca da consumação do tempo. Mas este processo é inseparável do sofrimento e da paixão, pois o Espírito exige a morte a fim de realizar a superação. Daí que a morte, em Hegel, seja o "trabalho do negativo" e aparente vencer a vida $\left({ }^{132}\right)$. No entanto, um Deus que é devir é a morte da morte, tal como paradigmaticamente já estava simbolizado na paixão de Cristo $\left({ }^{133}\right)$, pois este, símbolo supremo do sofrimento redentor, não é somente um viático de criação e de revelação, mas também de redenção, pelo que a história, como calvário do Espírito Absoluto, é o palco em que, na universalidade do seu espectáculo, se garante a vitória da vida sobre a morte e sobre o mal $\left({ }^{134}\right)$. E, bem vistas as coisas, este acesso salvífico, que as

\footnotetext{
${ }^{\left({ }^{128}\right)}$ Cf. idem, ibidem, pp. 159-160.

(129) A. Q., Prosas, vol. 1, p. 264.

$\left({ }^{130}\right)$ Idem, ibidem, p. 266.

${ }^{131}$ Idem, ibidem, pp. 266-267. Os sublinhados são nossos.

(132) Cf. Jean Brun, ob. cit., pp. 186-188.

${ }^{133}$ Cf. Hegel, Leçons sur la Philosophie de la Religion, Paris, 1954, pp. 159-160.

$\left({ }^{134}\right)$ Cf. Jean Brun, ob. cit., p. 187 ss.
} 
filosofias da história secularizaram e teorizaram, já está no cerne do drama cristão. É que, como escrevia o jovem Antero, "chega-se à crença pelo sofrimento, porque só ele nos pode dar a impressão profunda da necessidade duma compensação, o sentimento da justiça. É isto exactamente o que os sistemas não dão. Se Cristo tivesse filosofado, à maneira de Hegel, em face das dores de seu povo, não passaria o seu nome, hoje, de um desses que lemos, - ou antes não lemos nos in-fólios que tratam de arquivar as argúcias do espírito humano (...) Chorou, sentiu e sofreu com os mais tristes e os mais mesquinhos; é por isso que foi o Cristo" ( ${ }^{135}$ ).

Também para Antero a vida das nações (totalidades espirituais concretas) e dos indivíduos é mediada pelo transcurso do Espírito, e a necessidade ôntica da morte aparece como uma exigência metafísica para que os indivíduos, através da tomada de consciência da distância que existe entre a sua finitude e a infinitude do Ser a que devem aspirar, e entre realidade e idealidade, sejam impelidos a agir e, portanto, a passarem da visão passiva ou exclusivamente teorética da vida à sua assunção como seres práticos. Se o homem fosse amortal não seria um ente ético e histórico, e daqui decorre a necessidade metafísica de um Ser, que é devir, impor a inevitabilidade física da morte como condição essencial ao seu renascimento e à sua revelação permanentes $\left({ }^{136}\right)$. Como já se viu atrás, tudo isto dá à história empírica, ou melhor, concreta, uma dimensão dramática, que só a metafísica pode libertar da sujeição trágica através da compreensão do sentido do evoluir cósmico (e histórico). E este, assente na homologia entre o homem e o universo, revela-se como um telos que, dentro de um horizonte escatológico secularizado, aponta para a possibilidade do drama Ser terminar na libertação final pelo Bem.

\section{A Revolução como o Cristianismo do Mundo Moderno}

Depois deste excurso, julgamos estar em condições para perceber melhor por que é que Antero viu filosoficamente a revolução como

\footnotetext{
(135) A. Q., Cartas, vol. 1, p. 26.

( $\left.{ }^{136}\right)$ Desenvolvemos este tema no nosso trabalho, ainda inédito, $A$ Ideia de Morte emAntero.
} 
uma revelação, ou melhor, como uma espécie de actualização secularizada do cristianismo. Cristo, para além da sua existência histórica, foi interpretado como um símbolo e como a expressão de uma época, e a sua mensagem foi valorizada como um avançoem relação ao politeísmo, fundamentalmente porque reafirmou a superioridade da consciência e criou a ideia de humanidade. Mas convém relembrar que, para a apropriação secularista do cristianismo, se foi este que criou a humanidade, foi a humanidade que o criou a ele, pelo que Cristo não deve ser visto como a encarnação de Deus, mas tão-só como o filho do homem - o filho da humanidade - e como um dos grandes precursores da sua emancipação futura:

"Do pobre que protesta foste a imagem:

Um povo em ti começa, um homem novo:

De ti data uma trágica imagem

Por isso nós, a Plebe, ao pensar nisto,

Lembraremos, herdeiros desse povo,

Que entre nossos avós se conta Cristo" $\left({ }^{137}\right)$.

De facto, o uso secularizado do paradigma cristológico na definição da ideia de revoluçãoéuma constanteem Antero (como jáanteriormente o havia sido no romantismo social e particularmente em Edgar Quinet, embora este tivesse em vista, essencialmente, o completamento da Revolução Francesa e não tanto o ideal de uma nova revolução) $\left({ }^{138}\right)$. Em 1866, em carta a Alberto Sampaio escrita de Paris, caracterizava a sua expectativa revolucionária nestes termos: "Enquanto à Revolução seria longo dizer o a que tenho chegado, mas resumo afirmando que pode haver cedo e muito um cataclismo, muita desordem e confusão; a doutrina e a ordem real, porém, essa não se estabelece de uma vez: é uma grande renovação da Humanidade: gastará séculos,

\footnotetext{
$\left({ }^{137}\right)$ A. Q., Sonetos, Lisboa, 1963, p. 55. Com isto, pretende-se sugerir que esta invocação revolucionária de Cristo é tributária de uma das mais frequentes apropriações cristológicas feitas pelo pensamento revolucionário moderno desde a Revolução Francesa, com particular relevo no período do romantismo social (meados do séc. XIX). Cf. Frank Paul Bowman, Le Christ Romantique, Genève, 1973. Para o caso português, veja-se Maria Manuela Tavares Ribeiro, Portugal e a Revolução de 1848, Coimbra, 1990, p. 211 ss.

$\left.{ }^{138}\right)$ Cf. E. Quinet, Le Christianisme et la Révolution française, Paris, 1845.
} 
acções e reaç̧̃̃es sem conto para chegar a afirmar-se, como o Cristianismo ( $\left.{ }^{139}\right)$ "; e, em 1871, via o grupo que lançava as bases da Internacional e as Conferências do Casino - "os adeptos e os iniciados da Nova Lei da Justiça humana e social" - como "uma irmandade, como uma ordem religiosa espalhada pelo mundo", uma "Ecclesia pressa dum novo cristianismo, que em breve triunfará (...) porque temos a certeza que a Justiça é inevitável como uma Lei do Universo" $\left({ }^{140}\right)$. E esta analogia está de acordo com a fórmula com que ele terminou a sua conferência do Casino: "O Cristianismo foi a Revolução do mundo antigo: a Revolução não é mais do que o Cristianismo do mundo moderno" ${ }^{(141)}$.

Quer isto significar que, se o cristianismo foi um passo necessário dado pela humanidade na construção da sua unidade e na afirmação da sua aspiração íntima à liberdade, não de alguns, mas de todos, caberia à revolução iniciar a consumação pacífica e consciente do finalismo histórico. Daí que as filosofias da história da modernidade tenham igualmente secularizado a dimensão profética da concepção judaico-cristã do tempo. Os profetas são os anunciadores de um sentido escatológico do destino do homem. E pode dizer-se que é característica típica do romantismo social - "tempo de profetas" - atribuir aos intelectuais uma função idêntica, devendo estes dar "voz" ao "génio profético do pensamento de uma futura revolução" ( $\left.{ }^{142}\right)$, ou melhor, ao Ser que só na sua encarnação histórica pode compreender-se como consciência. Só que, agora, essa profecia não seria exclusivamente subjectiva (como em 1848), mas teria igualmente uma componente de previsão objectiva decorrente dos ensinamentos das ciências e da reflexão filosófica $\left({ }^{143}\right)$.

É que, recorde-se, com Hegel. a história tornou-se desvelamento de Deus, na dupla acepção do termo: é nela e por ela que Ele se descobre a si mesmo, no processo diacrónico de construção dialéctica de si próprio, ou melhor, ela é, em última análise, a paixão de Cristo incessantemente recomeçada, à luz da qual o paulino princípio "nós

\footnotetext{
$\left.{ }^{139}\right)$ A. Q., Cartas, vol. 1, p. 86. Os sublinhados são nossos.

$\left({ }^{140}\right)$ Idem, ibidem

(141) A. Q., Prosas, vol. 2, p. 140.

(142) Cartas, vol. 1, p. 209. Os sublinhados são nossos.

(143) Isto é, na prognose sobre a revolução futura, haveria não só "profecia, [mas] também um bocado de previsão" (Idem, ibidem).
} 
somos, nós vivemos e nós movemo-nos em Deus" pode ser completado por esta correç̧ão secularista: graças à história, que é o teatro em que Deus se realiza e assume consciência de si. Assim, se na lógica do criacionismo transcendente cristão se pode dizer - concluía Antero que Ele "É o Alfa e o Omega: depois de muitos trabalhos e meditações, (...) somos levados hoje a dizer que Deus é o Omega e o Alfa" $\left({ }^{144}\right)$, modo outro de confirmar que, afinal, nas filosofias de fundo teleológico, o Fim mais não é do que a explicitação temporal do Princípio, ilação que nos permite concluir que, tal como em Hegel, também em Antero a concepção irreversível do tempo se dá dentro de uma visão que não rompe por inteiro com a circularidade característica do historicismo oitocentista (o Fim é tão-somente a explicitação temporal de um Princípio definido como potência infinita).

No entanto, regressando ao horizonte cristológico anteriano, já não surpreende que, para ele, a revolução seja, em última análise, "o nome que o sacerdote da história, o tempo, deixou cair sobre a fronte fatídica do nosso século. Como do seu Deus dizia o apóstolo antigo, in eo vivimus et sumus, podemos nós", escreveu em 1865, "com mais razão ainda afirmar do grande espírito de revolta da nossa idade - nele e por ele é que somos, por ele e nele é que vivemos" ${ }^{145}$ ). Deste modo, se a revolução era tarefa para cientistas, a compreensão íntima do Ser momento privilegiado da revelação do Verbo imanente à história mostrava que os verdadeiros revolucionários tinham de estar para a anunciação do futuro como os apóstolos antigos estiveram para o anúncio do seu Deus, isto é, deviam comportar-se como "apóstolos de um Evangelho tão grande que pode conter no seio todos quantos têm pregado ao norte e ao sul, os Cristos de todas as raças e de todas as cores. Estes são, finalmente, a Igreja militante da Revolução" $\left({ }^{146}\right)$; seriam, em suma, a vanguarda espiritual da "pequena igreja de trabalhadores ad majorem Revolutionis gloriam" $\left({ }^{147}\right)$, ou, recorrendo à analogia usada pelo próprio Antero, teriam de desempenhar, na crise contemporânea, uma função de certo modo idêntica à que os velhos cristãos desempenharam no mundo romano, no tempo dos Antoninos $\left({ }^{148}\right)$.

\footnotetext{
$\left({ }^{144}\right)$ Cartas, vol. 1, p. 316.

(145) Idem, Prosas, vol. 1, p. 306.

(146) Idem, ibidem, p. 313.

$\left({ }^{147}\right)$ Idem, Cartas, vol. 1, p. 199.

$\left.{ }^{148}\right)$ Idem, ibidem, vol. 2, p. 718. De notar que esta analogia entre a crise do mundo
} 


\section{Política, História e Revolução}

Isto mostra que, concomitantemente com a dimensão científica, que Antero também invocava para se demarcar das construções utópicas à 1848, a sua ideia de revolução remetia para uma expectativa de horizonte imanentista, justificada por um telos que mostrava ao homem, concreto e finito, que o intervalo da sua vida não chegava para preencher a diferença entre o que já existe e o que ainda não existe, base ontologica que nos permite concluir que, afinal, a utopia, que a ciência expulsava pela porta, acabava por entrar pela janela aberta pela filosofia da história. E, passada a conjuntura em que ele acreditou estar próximo o início da revolução - finais dos anos 60, início da década de 70 -, esta componente foi-se acentuando. $E$ se, na primeira fase, $o$ revolucionário, visto como o apóstolo da "ideia nova" e do "homem novo", consubstanciava o profetismo histórico, com a maturidade e com a consolidação da certeza de que as formas históricas de objectivação do Espírito só seriam duradouras se postulassem uma radical transformação interior das consciências, o papel de guia da humanidade fixou-se na apologia do ideal de santidade, definido como a atitude existencial que mais autenticamente traduzia a fusão da subjectividade com a essência imperativa de um Ser que o homem transcendental, isto é, liberto do determinismo da natureza, pode intuir como pura aspiração à realiza-ção da ideia de Bem.

Defacto, se a substância necessariamente se objectiva como natureza e como história, a fim de assumir consciência de si, esta só é alcançável quando o homem se despoja da centração egóide do mundo e ascende a uma visão transcendental $\left.{ }^{(149}\right)$. Só a esse nível ele realiza verdadeiramente a liberdade. Aí, atinge-se, não um estado de "resignação", mas de "exultação" impessoal resultante da plena fusão do eu com o ideal: - "vivendo cada vez mais para os outros, sentindo morrer em cada dia dentro de si uma parcela do eu egoísta que tanto nos ilude, tanto nos faz sofrer e errar", o eu entra "gradualmente naquela região da impersonalidade que é a verdadeira beatitude" $\left({ }^{150}\right)$. E esta é sinonimo de liberdade, porque, na linha de Espinosa e de Hegel (e do in-

contemporâneo e a crise do mundo romano recebeu a sua mais profunda aplicação na obra de Oliveira Martins.

$\left({ }^{149}\right)$ Sobre esta questão, veja-se Fernando Catroga, "O Optimismo Transcendental de Antero", JL-Jornal de Letras, Artes e Ideias, n. ${ }^{\circ} 466$, Lisboa, 11 de Junho de 1991, pp. 12-13.

(150) A. Q., Cartas, vol. 2, p. 943. 
condicionado búdico), e no rigoroso sentido da palavra, a liberdade é "a espontaneidade quando plena", momento em que o Ser, "não já espontâneo apenas na sua actividade exteriormente condicionada (...), o é ainda nessa mesma condicionalidade, criando conscientemente os motivos das suas motivações e criando-os em vista do próprio fim. Neste ponto culminante, o motivo da determinação identifica-se com a essência e o fim do ser que se determina: este, conformando-se com o motivo, conforma-se consigo mesmo" ( $\left.{ }^{151}\right)$; funde-se o sujeito com $o$ objecto, e nesta experiência quase mística, o eu, liberto dos condicionalismos da realidade, apreende a sua essência, e, simultaneamente, a essência do próprio universo, ou melhor, o telos que sobredetermina o devir universal. Explica-se, assim, que, na linha de tradição mística alemã de base neoplatónica - que Hegel prolongou -, Antero tenha concluído que "esta perfeita identificação do $e u$ com a essência absoluta, por onde a sua primitiva espontaneidade se define finalmente como liberdade, é que é a essência do bem" ${ }^{152}$ ).

Portanto, o Bem é o movimento final e mais íntimo da evolução do Ser, experiência interior em que o Espírito se liberta de todas as suas limitaçðes, criando em si, de si, e para si um mundo completo e definitivo. Isto é, "o universo só dura pelo bem que nele se produz" $\left({ }^{153}\right)$. Mas, como só na consciência humana o Ser pode elevar-se à consciência de si, só o homem pode realizar o fim imanente ao devir universal, mostrando que, afinal, a "paixão do Espírito Absoluto", no seu viático pela natureza e pela história, não é errante como o de Ahasvérus, pois a sua peregrinação dramática como tempo "termina na libertação final pelo bem" $\left({ }^{154}\right)$. À luz desta aspiração, tem de se concluir que o pensamento de Antero reflecte com clareza o dilema típico do historicismo moderno: o homem é histórico precisamente porque procura libertar-se da história, dado que esta mais não é do que a resultante do longo percurso dos esforços humanos para fugir ao tempo, realizando a idealidade. Mas é também por isso que nele se encontra um dos apelos nucleares das filosofias oitocentistas da história: - o homem deve projectar, no tempo, o modelo divino que está dentro dele; deve esculpir a sua própria estátua, como pretendia

\footnotetext{
(151) Idem, Prosas, vol. 3, p. 123.

(152) Idem, ibidem, p. 131.

(153) Idem, Cartas, vol. 2, p. 953.

(154) Idem, Prosas, vol. 3, p. 134
} 
Plotino. Mas, enquanto este procurava alcançar o caminho descendente da emanação, o iluminismo e o romantismo incitavam a história a aproximar o homem do modelo divino, que a cultura extraía do seu próprio interior, para o objectivar, numa representação escatológica secularizada, como promessa que a humanidade devia cumprir $\left({ }^{155}\right)$.

A mediação do Espírito implicava, porém, que os indivíduos e as nações jamais pudessem ser contemporâneos desta completude, pelo que, à subjectividade, ao homem concreto, restava-lhe antecipar interiormente a finalidade que o verdadeiro saber anunciava. O que exigia a "morte" e a "superação" do eu empírico e a ascensão à impersonalidade do eu universal, experiência radical em que se funde a essência com a existência. Isto significa que só o santo, laico e franciscano, pode ascender à revelação do Ser, pois só nele se concretiza a existência autêntica, exultação intensa em que "a vida da nossa alma, do misterioso e sublime $e u$ que somos no fundo", "esse $e u$ ou essa alma [que] tem a sua esfera na região do impessoal", atinge o "mundo da abnegação, da pureza, da paciência, do contentamento", através da "renúncia do indi víduo natural e de tudo quanto o limita" $\left({ }^{156}\right)$. E é neste estádio de beatitude que o verdadeiro $e u$ cumpre "a sua misteriosa individualidade" ( $\left.{ }^{157}\right)$; só nesse ácume de santidade se alcança a liberdade, pois, "para o santo, o mundo cessou de ser um cárcere: ele é, pelo contrário, o senhor do mundo, porque é o seu supremo intérprete. Só por ele é que o Universo sabe para que existe: só ele realiza o fim do Universo" ( $\left.{ }^{158}\right)$. Com isto, Antero dava expressão à ideia essencial que bebeu na Teologia Germânica e em Hegel: - Deus si ganha consciência de si na sagesse humana $\left({ }^{159}\right)$.

Em conclusão: a metafísica mostrava queé aética que sobredetermina a história, ou melhor, a objectivação histórico-social do Espírito, pois "a sociedade é, antes de tudo, um facto de ordem moral" $\left({ }^{160}\right)$, e os factos sociais, "sem as ideias que os vivificam, são inertes e incompreensíveis, são corpos sem alma" $\left({ }^{161}\right)$, ilação que, no que respeita à

\footnotetext{
(155) Jean Brun, ob. cit., p. 145.

(156) A. Q., Cartas, vol. 2, p. 710.

$\left({ }^{157}\right)$ Idem, ibidem.

(158) Idem, ibidem, p. 838. Os sublinhados são nossos.

(159) Jean Brun, ob. cit., p. 193.

(160) A. Q., Cartas, vol. 2, p. 809.

(161) Idem, Prosas, vol. 2, p. 49.
} 
ideia de socialismo, tinha como resultado a tomada de consciência do inevitável desfasamento que existe entre a Ideia (e o Ideal) e a sua limitada concretização fenomenológica, ou melhor, entre o sentido objectivo das coisas (que a ciência analisa e a metafísica clarifica) e as condições subjectivas necessárias a que o Ideal passe de possibilidade a acto. Em termos sociais, isto tinha de traduzir-se num modo ético de estar no mundo e de o transformar que fosse capaz de superar o individualismo. $\mathrm{O}$ que requeria uma autêntica metanoia capaz de ultrapassar os limites de uma mundividência centrada no eu pessoal, base ôntica (e ética) do individualismo e do utilitarismo dominantes nas sociedades liberais de então. Só a assunção do sujeito como $e u$ universal poderia fazer nascer o "homem novo" prometido pela revolução ${ }^{162}$ ), pelo que a construção do socialismo tinha de estar indissoluvelmente ligada à urgente reforma espiritual que, não só Portugal, mas toda a sociedade ocidental teria de levar a cabo, sob pena de continuar mergulhada numa decadência irreversível.

Em suma: pode mesmo sustentar-se que o ideal socialista constituía a mais adequada encarnação histórica do finalismo que move o próprio devir universal. Quer isto dizer que é a sua raiz metafísica e ontológica que dita o seu significado sócio-político. É que, recorde-se, se o universo aspira à liberdade, só o espírito humano a realiza, e os que viam a historia comoum meroprolongamentoda natureza desconheciam o sentido radical da sua evolução. E este, já "dormente e profundamente soterrado no mundo inorgânico", isto é, manifestando-se de um modo inconsciente, "é nos seres conscientes, é na sociedade humana que a razãoencontra o seu órgão", peloque, sendo "oprogressodahumanidade (...) um facto de ordem moral" $\left({ }^{163}\right)$, a objectivação do fim da história

(162) Como se sabe, a reactualização do mito do "homem novo" feita pelos vários projectos revolucionários modernos, a começar pela Revolução Francesa, assenta na secularização das expectativas escatológicas inerentes ao baptismo religiosoe à crença na ressurreição final dos corpos. Cf. Bronislaw Baczko, "Former l'homme nouveau. Utopie et pédagogie pendant la Révolution Française", Libre, n. ${ }^{\circ} 8,1986$, pp. 89-132; Antoine de Baecque, "L'Homme Nouveau est arrivé. La'Régénération' des Français en 1789", Dix-Huitième Siècle, n. ${ }^{\circ} 20,1988$, p. 191 ss; Mona Ozouf, L'Homme Régénéré, Paris, 1989, pp. 132-140, 150-154. Sobre a incidência do ideal de "homem novo" no imaginário político republicano, veja-se Fernando Catroga, O Republicanismo em Portugal Da formação ao 5 de Outubro de 1910, Coimbra, 1991, pp. 449-460.

(163) A. Q., Prosas, vol. 3, p. 129. 
teria de coincidir com a realização dos imperativos que, na sua conversão interior, o homem descobre como análogo à ideia-tipo que o deve nortear: - a ideia de Bem.

Assim sendo, o socialismo prometia aproximar-se historicamente do Omega (e do Alfa) do devir universal. Mas, como essa epopeia remete para uma raiz ética, a sua construção tinha de assentar em pressupostos morais, aparecendo como corolário lógico que, para Antero, pelo menos para o Antero da última década da sua vida, o santo fosse o homem de aç̧ão por excelência, porque a sua prática vai toda no sentido do Bem (santidade que, no entanto, não era cenobita nem quietista). $O$ verdadeiro santo é um místico activo, homem prático à sua maneira, pois a sua vida constitui um foco de espiritualidade decorrente da fusão da sua essência com a sua existência, isto é, do Ser com o Dever-Ser, que nele exemplarmente se revela. Nesta perspectiva, percebe-se melhor por que é que Antero via o socialismo como uma ilação simultaneamente científica e filosófica, e compreende-se que ele, ainda em 1889, citando o seu velho mestre Proudhon - que já em 1868 caracterizava como "[São João] baptista da era futura" $\left({ }^{164}\right)$ tenha voltado a defender que "o mundo só pela moral será libertado e salvo" $\left({ }^{165}\right)$. Portanto, o socialismo será o modo empírico, isto é, histórico, que mais se aproximará da consumação da ideia de Bem, pelo que se pode então afirmar que ele, ao realizar a história, estará igualmente a realizar a filosofia. E, "como causa alguma grande e duradoura se fundou ainda no mundo senão pela moral", explica-se que, mesmo para o Antero daquele período, o socialismo só pudesse ser "uma explêndida realidade" se fosse vivido, não somente como um ideal económico, político ou jurídico, mas também, e sobretudo, "como um passo mais no caminho da evolução moral das sociedades" $\left({ }^{166}\right)$.

(164) A. Q. Cartas, vol. 1, p. 106.

(165) A. Q., Prosas, vol. 3, p. 143.

( $\left.{ }^{166}\right)$ Idem, ibidem, p. 141. 